\title{
ORIGINALITY AND CREATIVITY IN COPYRIGHT LAW
}

\author{
Howard B. Abrams*
}

I

\section{INTRODUCTION}

Copyright inevitably pits the demands of authors and publishers to control and charge for uses of their works against the demands of consumers and users of these works for maximum access to the works at minimal or no cost. Indeed, the basic rationale for copyright is that the benefit derived from an essentially monopolistic set of legal rights, which provide the necessary economic incentive for the creation and dissemination of aesthetic and intellectual works, outweighs the added costs that the copyright monopoly imposes on the public. The benefit to the public is the plentiful supply and widespread distribution of aesthetic and intellectual works. The added costs to the public take two forms, the added expense for copies or rights to use the copyrighted work whose price is set by the copyright owner without any fear of legitimate competition, and the restrictions on using the prior work to create further works. As the elements of copyright that affect the balance change, so too will the costs and benefits of the copyright system.

Copyright law can be broadly viewed as a system seeking an appropriate legal balance between the rights of authors and publishers on one hand and the rights of users and consumers on the other. Many issues in copyright law directly affect how this balance is drawn, ranging from the constitutional limitation of the copyright monopoly to the "Writings"' of "Authors,"2 with its corollary requirement that a work be original to qualify for copyright protection, ${ }^{3}$ to such statutory or judicial limitations as the "idea-expression"

Copyright $\odot 1992$ Howard B. Abrams. All rights reserved.

* Professor of Law, University of Detroit Mercy School of Law.

The author would like to thank the members of the staff of Law and Contemporary Problems who worked on this article, Rebecca Denson, Robert Kohn, Mark Weinberger, and Don Willett.

1. The Constitution provides: "The Congress shall have Power ... [t]o promote the Progress of Science and useful Arts, by securing for limited Times to Authors and Inventors the exclusive Right to their respective Writings and Discoveries." US Const, Art I, § 8, cl 8. The Supreme Court has interpreted the term "Writings" expansively "to include any physical rendering of the fruits of creative intellectual or aesthetic labor." Goldstein v Califormia, 412 US 546, 561 (1973).

2. The Supreme Court's widely cited definition of "author" is "he to whom anything owes its origin; originator; maker; one who completes a work of science or literature." Burrow-Giles Lithographic Co. $v$ Sarony, 111 US 53, 58 (1884). As authority, the Supreme Court cites only "Worcester." This may have been a reference to Joseph E. Worcester, A Comprehensive and Explanatory Dictionary of the English Language: with Vocabularies of Classical, Scripture and Modern Geographical Names (Hickling, Swan \& Brewer, 1860).

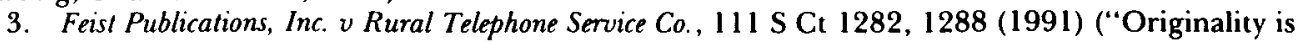
a constitutional requirement."); Burrow-Giles Lithographic Co., 111 US at 58; The Trademark Cases, 100 


\section{distinction, ${ }^{4}$ standards for determining infringement, ${ }^{5}$ and the affirmative defense of fair use. ${ }^{6}$}

Eligibility for copyright protection, or, more colloquially, copyrightability, is one of the major components of the balance drawn by copyright law between the competing claims of copyright owners and copyright users. ${ }^{7}$ The question of originality, the threshold standard of qualification for copyright protection, is at the core of copyrightability. ${ }^{8}$ Defining or redefining this

US 82 (1879). See generally Howard B. Abrams, The Law of Copyright § 1.02[C][4] (Clark Boardman, $1991)$.

4. 17 USC $\S 102(b)$. The "idea-expression" distinction derives from the case of Baker $v$. Selden, 101 US 99 (1880). See generally Abrams, The Law of Copyright at $\$ 3.03$ (cited in note 3).

5. Infringement is defined as the violation of any of the exclusive rights of the copyright owner. 17 USC $\$ 501$ (a) (1988). Infringement does not present difficult conceptual problems where the allegedly infringing work is a verbatim copy of the original work. Where the plagiarism is more subtle, the standards for determining what is infringing and what is legitimate use of earlier works becomes more difficult and has a profound impact on the balancing of rights between copyright owners and the users of copyrighted works. See generally, Abrams, The Law of Copyright at ch 14 (cited in note 3 ).

6. 17 USC 8 107. See generally Abrams, The Law of Copyright at ch 15 (cited in note 3).

7. The issue of copyrightability must be kept separate from the issue of the scope of copyright protection. Even if a work is protected by copyright, the protection does not extend "to any idea, procedure, process, system, method of operation, concept, principle, or discovery, regardless of the form in which it is described, explained, illustrated, or embodied in such work." 17 USC $\$ 102$ (b). This issue is usually framed in terms of a distinction between the ideas contained in a work and their expression, often phrased as the "idea-expression dichotomy." See generally Abrams, The Law of Copyright (cited in note 3 ).

8. There are other limitations on which works are eligible for copyright protection. For example, a work must belong to a category that is eligible for copyright protection under the Copyright Act, either as one of the classes of work listed in section 102(a), 17 USC $\$ 102$ (a) (1988), amended by Architectural Works Copyright Protection Act, Pub L No 101-650, tit VII, § 703, 104 Stat 5133 (1990), or as a compilation or a derivative work. 17 USC $\$ 103$ (1988); see also 17 USC $\$ 101$ (1988) (definitions of "compilation" and "derivative work"). Section 102(a) lists eight classes of "works of authorship": literary works; musical works; dramatic works; pantomimes and choreographic works; pictorial, graphic and sculptural works; motion pictures and other audiovisual works; sound recordings; and architectural works. Congress deliberately chose to use the term "works of "authorship" in the Copyright Act rather than the constitutional terminology of "Writings" of "Authors" to "avoid exhausting the constitutional power of Congress to legislate in this field, and to eliminate the uncertainties arising from the latter phrase." HR Rep No 1476, 94th Cong, 2d Sess 51 (1976); S Rep No 473, 94th Cong, lst Sess 50 (1975). This made it possible for Congress to exclude such works as typeface designs from copyright protection, HR Rep No 1476, at 51; S Rep No 473, at 50, without any tension between the legislative exclusion and the statutory language of inclusion. Thus Congress was able to exclude typeface designs and dress designs from copyright protection, HR Rep No. 1476, at 55, which would likely be regarded as constitutional "Writings."

In addition, official governmental actions such as judicial opinions or statutes are categorically denied copyright protection. Wheaton v Peters, 33 US (8 Pet) 591 (1834) (Supreme Court's opinions); Callaghan v Myers, 128 US 617, 647 (1888) (state court opinions); Banks v Manchester, 128 US 244, 253-254 (1888) (state court opinions); Howell v Miller, 91 F 129 (6th Cir 1898) (state statutes) (Harlan); Davidson v Wheelock, 27 F 61 (CCD Minn 1866) (state statutes); Georgia v Harrison Co., 548 F Supp 110 (ND Ga 1982) (state statutes), vacated by agreement between the parties, $559 \mathrm{~F}$ Supp 37 (ND Ga 1983); see also West Publishing Co. v Mead Data Central, Inc., 799 F2d 1219, 1223 n2 (8th Cir 1986) ("West does not and could not claim any copyright in the judicial opinions themselves," but preliminary injunction protecting the pagination of West's reporters upheld); Building Offrials $\&$ Code Administrators International, Inc. v Code Technology, Inc., 628 F2d 730, 736 (Ist Cir), rev'g 210 USPQ 289 (D Mass 1980) (reversing preliminary injunction protecting local building code adopted from copyrighted model building code, but "leav[ing) the door slightly ajar" so the issue could ultimately be decided on a full evidentiary record). See generally L. Ray Patterson \& Craig Joyce, Monopolizing the Law: The Scope of Copyright Protection for Law Reports and Statutory Compilations, 36 UCLA L Rev 719, 
threshold standard has serious consequences for the copyright system. If the standards for a work to be considered original, and thus qualify for copyright protection, are raised or lowered, both the number and types of works that can claim copyright protection will change. Thus what is at stake in any definition or redefinition of originality is the coverage of the copyright monopoly and the balance between copyright owners and users at its most basic level.

In Feist Publications, Inc. v. Rural Telephone Service Co., ${ }^{9}$ the Supreme Court for the first time squarely addressed the issue of the degree of creativity necessary to sustain a copyright in a compilation of factual material. On the immediate issue before it, the Court held that a directory containing an alphabetical list of telephone subscribers, together with their towns and telephone numbers failed to satisfy the constitutional standard of originality necessary for copyright protection. In doing so, the Court engaged in a fundamental reexamination and reformulation of the concept of originality applicable to all works of authorship, not merely those consisting of compilations of factual material. Feist provides a new basic starting point that promises to have a broad impact on not only the concept of originality, but on the underlying jurisprudence of copyright.

This article first recounts the origin and development of the originality standard prior to the Feist decision. ${ }^{10}$ It then analyzes the Feist opinion, ${ }^{11}$ examines the impact of $F$ eist on the issue of originality, ${ }^{12}$ and looks at cases that have been decided after Feist. ${ }^{13}$ Finally, the article attempts to look at the practical and doctrinal implications of Feist for the future. ${ }^{14}$

II

\section{The Requirement OF ORIGINALITY}

\section{A. In General}

The copyright-patent clause of the Constitution empowers Congress to grant copyright protection to the "Writings" of "Authors."15 In two early cases, the Supreme Court grounded the requirement of originality in the

728-749 (1989); Abrams, The Law of Copyright at $\$ 2.05$ [A] (cited in note 3). For the federal government, the prohibition of copyrightability has been statutorily extended to "any work of the United States Government." 17 USC $\$ 105$ (1988).

Finally, works published in nations that do not extend copyright protection to the works of American authors and publishers are also denied American copyright protection. 17 USC $\S 104$ (1988); see generally Abrams, The Law of Copyright at $\$ 2.05[B]$ (cited in note 3). This exclusion is a discrete response to the specific problem of international reciprocity of copyright protection rather than being based on any overall parameters for balancing rights of authors, publishers and copyright users.

9. 111 S Ct 1282 (1991), rev'g 916 F2d 718 (10th Cir 1980) (unpublished opinion), aff'g 663 F Supp 214 (D Kan 1987).

10. See text accompanying notes 15-39.

11. See text accompanying notes 40-67.

12. See text accompanying notes 68-106.

13. See text accompanying notes 107-178.

14. See text accompanying notes 179-222.

15. US Const, Art I, $\S 8, \mathrm{cl} 8$, quoted in note 1 . 
constitutional language. In The Trademark Cases, ${ }^{16}$ the Supreme Court stated that "originality is required" 17 for anything to be classified as the writing of an author. The Court continued: "[W]hile the word writings may be liberally construed, as it has been, ... it is only such as are original, and are founded in the creative powers of the mind. The writings which are to be protected are the fruits of intellectual labor, embodied in the form of books, prints, engravings, and the like."18 In Burrow-Giles Lithographic Co. v. Sarony, ${ }^{19}$ the Supreme Court defined "author" as "he to whom anything owes its origin; originator; maker; one who completes a work of science or literature.' "20 The Court, however, did not attempt to define the requisite originality. ${ }^{21}$ If the author of a work is defined as its originator, it follows that a work must have the characteristic of being original, or at least being originated, to be eligible for copyright protection.

Stating that a work must be "original" to qualify for copyright protection begs the question of what definition of originality shall be chosen. The Supreme Court first addressed this issue in Bleistein $v$. Donaldson Lithographing Co., ${ }^{22}$ a suit for the infringement of three chromolithographed posters advertising a circus. A directed verdict for the defendant was sustained by the court of appeals, which took the position that if a "picture has no other use than that of a mere advertisement, and no value aside from this function, it would not be promotive of the useful arts, within the meaning of the constitutional provision, to protect the 'author' in the exclusive use thereof, ...,",23 and held that it could not find "anything useful or meritorious in the design copyrighted by the plaintiffs in error other than as an advertisement . . . ."24 The Supreme Court reversed. Speaking for the majority, Justice Holmes redefined the issue of copyrightability by focusing on the contribution of the author necessary for copyrightability rather than the purpose to which

16. These three cases, United States $v$. Steffens, United States v. Witteman, and United States v. Johnson, are jointly decided at 100 US 82 (1879). These cases challenged the constitutionality of the first federal trademark act. The Supreme Court held that trademarks could not be protected by Congress as either "Writings" or "Discoveries" under the copyright-patent clause because many trademarks lacked originality. On the commerce clause issue, the Court held the statute invalid because the scope of the statute enacted by Congress would include intrastate commerce as well as interstate commerce.

17. Id at 94 .

18. Id (emphasis in original).

19. 111 US 53 (1884).

20. Id at 58, citing "Worcester." See note 2.

21. Burrow-Giles involved the claim to copyright a photograph of Oscar Wilde. Issues raised by the defense included that a photograph was not the product of a constitutional "Author," but the end result of a mechanical process. The photograph was a portrait involving a highly contrived pose and background, and the Court had no trouble in finding the requisite authorship in the photographer's posing of the subject, arrangement of the background draperies, and so on. Although its chosen definition of "Author" did much to embed "originality" as the term of art for the standard for copyrightable authorship, Burrow-Giles did not actually provide a definition of originality.

22. 188 US 239 (1903).

23. Courier Lithographing Co. v Donaldson Lithographing Co., 104 F 993, 996 (6th Cir 1900), rev'd and remanded sub nom Bleistein $v$ Donaldson Lithographing Co., 188 US 239 (1903).

24. Id. 
the work was put. Justice Holmes then gave what has become the seminal description of originality:

The copy is the personal reaction of an individual upon nature. Personality always contains something unique. It expresses its singularity even in handwriting, and a very modest grade of art has in it something irreducible, which is one man's alone. That something he may copyright unless there is a restriction in the words of the act. ${ }^{25}$

Following Bleistein, later judicial statements described originality in terms of individual effort without regard to any degree of novelty or aesthetic merit. Eventually, originality came to be seen as requiring no more than the absence of plagiarism. ${ }^{26}$

The standard of originality was given an explicit statutory embodiment in the 1976 Act which limits copyright protection to "original works of authorship."27 Although the statute does not define originality, the Committee Reports clarify the intent of Congress to embody the standard of originality that had evolved in case law:

The phrase "original works of authorship," which is purposely left undefined, is intended to incorporate without change the standard of originality established by the courts under the present copyright statute. This standard does not include requirements of novelty, ingenuity, or esthetic merit, and there is no intention to enlarge the standard of copyright protection to require them. ${ }^{28}$

\section{B. Originality in Compilations of Facts}

Prior to the Feist decision, the question of what constituted the requisite originality for copyright protection in a compilation of facts proved troublesome for the courts. ${ }^{29}$ At issue was whether industrious gathering and listing of factual data was sufficient to qualify the work as original, or whether some additional element of authorship or judgment in the selection and arrangement of the individual units in the compilation was necessary.

The issue can be stated in more precise factual and doctrinal terms. Even before Feist, it was a well-established principle in copyright law that there can be no copyright in a fact or in facts per se. ${ }^{30}$ The rationale for this doctrine is

25. Bleistein, 188 US at 250.

26. L. Batlin Ė Son v Snyder, 536 F2d 486, 490 (2d Cir 1976) (en banc), quoting Burrow-Giles, 111 US at 57-58 ("Originality means that the work owes its creation to the author and this in turn means that the work must not consist of actual copying."); Alfred Bell E' Co. v Catalda Fine Arts, Inc., 191 F2d 99, 102 (2d Cir 1951) (" 'Original' in reference to a copyrighted work means that the particular work 'owes its origin' to the 'author.' "); Hoague-Sprague Corp. v Frank C. Meyer Co., 31 F2d 583, 586 (EDNY 1929) ("[T]he originality required in case of copyright means little more than a prohibition of actual copying.").

27. 17 USC §102(a), amended by 104 Stat 5133 .

28. HR Rep No 1476 at 51 ; S Rep No 473 at 50 (both cited in note 8).

29. The Copyright Act provides that compilations are included in the subject matter of copyright. 17 USC $\S 103($ a) (1988). The definition of a compilation expressly incorporates a requirement of originalty. Id at $\$ 101$.

30. Harper E Row, Publishers, Inc. v Nation Enterprises, 471 US 539, 556 (1985) ("No author may copyright his ideas or the facts he narrates."); Konor Enterprises, Inc. $v$ Eagle Publications, Inc., 878 F2d 138,140 (4th Cir 1989) ("Although facts contained in a telephone directory are not protected by the copyright laws, the directory itself is protected as a unique compilation of those facts."); Financial Information, Inc. v Moody's Investors Service, Inc., 808 F2d 204, 207 (2d Cir 1986) ("Facts may not be copyrighted."); Financial Information, Inc. v Moody's Investors Service, Inc., 751 F2d 501, 505 (2d Cir 
that facts are not created or originated by the author of any work which embodies the facts; additionally, a larger public policy concern exists that copyright protection is not intended to restrict the public's use of facts or remove them from the public domain. ${ }^{31}$ Although facts in and of themselves are in the public domain and not copyrightable, courts have traditionally recognized copyright in many works which compile factual data, ${ }^{32}$ and the current Copyright Act expressly recognizes copyright in compilations. ${ }^{33}$ If facts are not copyrightable, why are collections of facts copyrightable?

An examination of the cases prior to Feist reveals two distinct standards being invoked by the courts to determine if a compilation of facts had the requisite originality to qualify for copyright protection. First, an approach, which has come to be known as the "sweat of the brow" test, accepts industry and effort as sufficient to establish originality even when such effort lacks imagination or judgment. This approach was most frequent in a series of cases which protected copyright in such works as alphabetical telephone directories, ${ }^{34}$ the very type of work at issue in Feist. These cases found the requisite originality for copyrightability in the effort, time, and money expended to create the compilation of uncopyrighted materials. This "sweat of the brow" test was stated in the following terms in the early case of Jeweler's Circular Publishing Co. v. Keystone Publishing Co.:

The man who goes through the streets of a town and puts down the names of each of the inhabitants, with their occupations and their street number, acquires material of which he is the author. He produces by his labor a meritorious composition, in which

1984); Miller v Universal City Studios, Inc., 650 F2d 1365, 1371-72 (5th Cir 1981); Hoehling v Universal City Studios, Inc., 618 F2d 972, 979 (2d Cir 1980) ("[F]actual information is in the public domain." Facts researched by novelist for novel portraying the explosion of the dirigible Hindenburg as an act of sabotage were not copyrightable.); Rosemont Enterprises v Random House, Inc., 366 F2d 303, 310 (2d Cir 1966) (biographical facts concerning Howard Hughes in copyrighted magazine article were not copyrightable).

31. Section 102(b) echoes this purpose, providing: "In no case does copyright protection for an original work of authorship extend to any idea, procedure, process, system, method of operation, concept, principle, or discovery, regardless of the form in which it is described, explained, illustrated, or embodied in such work." 17 USC $\$ 102(b)(1988)$. Certainly this section suggests that while facts and data may be discovered, they may not be protected by copyright.

32. Konor Enterprises, 878 F2d at 140 ("Although facts contained in a telephone directory are not protected by the copyright laws, the directory itself is protected as a unique compilation of those facts."); see also cases cited in notes $34,36-37,39$.

33. 17 USC $\$ 103(a)$.

34. See, for example, Konor Enterprises, 878 F2d 138 (telephone directory); Hutchinson Telephone Co. $v$ Fronteer Directory Co., 770 F2d 128, $131-32$ (8th Cir 1985) (telephone directory); Southern Bell Telephone E Telegraph Co. $v$ Associated Telephone Directory Publishers, 756 F2d 801 (11th Cir 1985); Schroeder $v$ William Morrow E Co., 566 F2d 3 (7th Cir 1977) (gardening directory); G. R. Leonard E' Co. $v$ Stack, 386 F2d 38 (7th Cir 1967); Hartfield v Peterson, 91 F2d 998 (2d Cir 1937) (cable and telegraphic code); Leon $v$ Pacific Telephone E Telegraph Co., 91 F2d 484 (9th Cir 1937) (telephone directory); Jeweler's Circular Publishing Co. v Keystone Publishing Co., 281 F 83 (2d Cir 1922) (directory of jewelers' trademarks); BellSouth Advertising Eै Publishing Corp. v Donnelley Information Publishing, Inc., 719 F Supp 1551 (SD Fla 1988), aff'd, 933 F2d 952 (1 l th Cir 1991) (telephone directory); Southwestern Bell Media, Inc. $v$ Trans Western Publishing Inc., 670 F Supp 899 (D Kan 1987); Rural Telephone Service Co. v Feist Publications, 663 F Supp 214 (D Kan 1987), aff'd, 916 F2d 718 (10th Cir 1990) (unpublished opinion), rev'd, 111 S Ct 1282 (1991); Central Telephone Co. v Johnson Publishing Co., 526 F Supp 838 (D Colo 1981); Southwestern Bell Telephone Co. v Nationwide Independent Directory Service, 371 F Supp 900 (WD Ark 1974). 
he may obtain a copyright, and thus obtain the exclusive right of multiplying copies of his work. ${ }^{35}$

Taking a different approach, the relatively recent opinions by the Second Circuit in Eckes $v$. Card Prices Update ${ }^{36}$ and Financial Information, Inc. v. Moody's Investors Service, ${ }^{37}$ insisted that the compilation must display originality in the "selection, creativity and judgment in choosing"38 the compiled materials. 39 These opinions reject the "sweat of the brow" approach, holding that effort alone can never satisfy the requirement of originality for a compilation.

\section{Feist Publications v. Rural Telephone Service}

The Supreme Court settled the controversy in Feist Publications $v$. Rural Telephone Service Co. ${ }^{40}$ a prototypical case involving the copying of at least 1,309 names, towns, and telephone numbers from a "white pages"

35. $281 \mathrm{~F} 83,88$ (2d Cir 1922), quoted in Hutchinson Telephone, $770 \mathrm{~F} 2 \mathrm{~d}$ at 131; Leon, $91 \mathrm{~F} 2 \mathrm{~d}$ at 486 .

36. 736 F2d 859 (2d Cir 1984).

37. 808 F2d 204 (2d Cir 1986) ("Financial Information II"); 751 F2d 501 (2d Cir 1984) ("Financial Information I"). The case involved daily issues of 4 " $\mathrm{x}$ 6" index cards printed with information concerning current municipal bonds being called for redemption. Typically, the information consisted of the identity of the issuing authority, the series of bonds being redeemed, the date and price of the redemption, and the name of the trustee or paying agent. The plaintiff expended considerable effort and money to cull the information from a variety of widely scattered sources.

Initially, the district court found the compilation was copyrightable, 599 F Supp 994 (SDNY 1983) (defendant's motion for summary judgment denied); 1984 Copyright $L$ Dec (CCH) I 25,617 (SDNY 1984) (opinion after trial), but the use of the plaintiff's material by the defendant was a "fair use" and thus was not an infringement. 1984 Copyright $L$ Dec (CCH) I 25,617 (SDNY 1984). The Second Circuit reversed the finding of fair use, but remanded to the trial court for further consideration of the issue of whether the material claimed by the plaintiff was original and copyrightable. 751 F2d 501 (1984). On remand, the district court found the material was not copyrightable, Copyright L Dec (CCH) I 25,960 (SDNY 1986), which was sustained by the Second Circuit on the second appeal. 808 F2d 204 (2d Cir 1986), cert denied, 484 US 820 (1987).

38. Financial Information II, 808 F2d at 207, quoting Eckes $v$ Card Prices Update, 736 F2d at 863.

39. The issue is not new to judicial thought. In 1902, the Seventh Circuit commented:

Little by little copyright has been extended to the literature of commerce, so that it now includes books that the old guild of authors would have disdained; catalogues, mathematical tables, statistics, designs, guide-books, directories and other works of similar character. Nothing, it would seem, evincing, in its makeup, that there has been underneath it, in some substantial way, the mind of a creator or originator.

National Telegraph News Co. v Western Union Telegraph Co., 119 F 294, 297 (7th Cir 1902) (holding ticker tapes listing telegraph transmissions of market quotations, sports scores, and race results were not copyrightable). See also Roy Export Co. Establishment of Vaduz, Liechtenstein v Columbia Broadcasting System, Inc, 672 F2d 1095, 1103 (2d Cir), cert denied, 459 US 826 (1982) (originality in selection of various public domain film clips); Kregos $v$ Associated Press, 731 F Supp 113 (SDNY 1990), aff'd in part and rev'd in part, 937 F2d 700 (2d Cir 1991); Dow Jones E Co. v Board of Trade, 546 F Supp 113, 116 (SDNY 1982) (originality found in selection of stocks to use in calculating stock market indexes); Triangle Publications, Inc. v Sports Eye, Inc., 415 F Supp 682 (ED Pa 1976). A number of earlier cases also focused on the subjective judgment exercised by the author in making the compilation as the source of originality, see, for example, Adventures in Good Eating, Inc. $v$ Best Places to Eat, Inc., 131 F2d 809 (7th Cir 1942); List Publishing Co. v Keller, 30 F 772 (CC SDNY 1887), but these cases typically found the work in question to be copyrightable. There are also cases which deny protection to lists of ingredients or contents. Kitchens of Sara Lee v Nifty Foods Corp., 266 F2d 541, 545 (2d Cir 1959); Gray v Eskimo Pie Corp., 244 F Supp 785, 788 (D Del 1965). The divergence between the "sweat of the brow" cases and the "selection and arrangement" cases, however, did not become acute until the Eckes and Financial Information opinions.

40. 111 S Ct 1282 (1991). 
alphabetical listing of telephone service subscribers.41 Rural Telephone Service, a public utility, was required by state regulation to issue an updated annual telephone directory listing the subscribers to whom it provided telephone service. As the sole provider of telephone service, Rural Telephone obtained the names and addresses of its subscribers directly from the subscribers. Feist Publications published a competing directory. When Rural Telephone refused to license its listings to Feist for an area-wide directory, Feist copied the listings without Rural Telephone's consent.

Rural Telephone sued for copyright infringement. The district court granted summary judgment for Rural Telephone on the copyright claim on the grounds that "[c]ourts have consistently held that telephone directories are copyrightable." 42 The Tenth Circuit affirmed the decision without opinion. ${ }^{43}$ The Supreme Court reversed. ${ }^{44}$

The Court held that a compilation would be original, and hence copyrightable, only if the "choices as to selection and arrangement . . are made independently by the compiler and entail a minimal degree of creativity" 45 in the selection and arrangement of the compiled data. In addition to focusing on the selection and arrangement of data as the crucial factual determinant of originality for a data compilation, the Court went out of its way emphatically and expressly to reject the "sweat of the brow" approach. ${ }^{46}$

The Court's opinion began with an admirably clear statement of the problem:

This case concerns the interaction of two well-established propositions. The first is that facts are not copyrightable; the other, that compilations of facts generally are. Each of these propositions possesses an impeccable pedigree . . . .

There is an undeniable tension between these two propositions. Many compilations consist of nothing but raw data-i.e., wholly factual information not accompanied by any original written expression. On what basis may one claim a copyright in such a work? Common sense tells us that 100 uncopyrightable facts do not magically change their status when gathered together in one place. Yet copyright law seems to contemplate that compilations that consist exclusively of facts are potentially within its scope. ${ }^{47}$

41. Id at $1287,1295-96$.

42. Rural Telephone Service Co. v Feist Publications, 663 F Supp 214, 218 (D Kan 1987). The district court was quite accurate in its summation of the string of cases concerning telephone directories, which had repeatedly and consistently upheld their copyrightability. Hutchinson Telephone Co., 770 F2d 128 (8th Cir 1985); Southern Bell Telephone \& Telegraph Co. v Associated Telephone Directory, 756 F2d 801 (11th Cir 1985); Leon v Pacific Telephone E Telegraph Co., 91 F2d 484 (9th Cir 1937); Central Telephone Co. v Johnson Publishing Co., 526 F Supp 838 (D Colo 1981); Southwestern Bell Telephone Co. v Nationwide Independent Directory Service, Inc., 371 F Supp 900 (WD Ark 1974); Southern Bell Telephone E Telegraph Co. $v$ Donnelly, 35 F Supp 425 (SD Fla 1940); Cincinnati $\Xi$ Suburban Bell Telephone Co. v Brown, 44 F2d 631 (S.D. Ohio 1930); Hartford Printing Co. v Hartford Directory Ev Publishing Co., 146 F 332 (D Conn 1906).

43. 916 F2d 718 (10th Cir 1980).

44. 111 S Ct 1282 (1991).

45. Id at 1289 (citations omitted).

46. Id at 1291-92.

47. Id at 1287 (citations omitted). 
The Court first examined the reason for denying copyrightability to facts per se. Based on The Trade-Mark Cases ${ }^{48}$ and Burrow-Giles Lithographic Co. $v$. Sarony, ${ }^{49}$ the Court held that originality is a constitutional requirement arising out of the use of the terms "Authors" and "Writings" in the Copyright Clause. 50 Accepting the definition of "author" adopted in Burrow-Giles as "he to whom anything owes its origin; originator; maker," 51 as the constitutional standard, the Court ruled that a fact could never be protected by copyright because it was not the creation of an author. The Court reasoned:

[F]acts do not owe their origin to an act of authorship. The distinction is one between creation and discovery: the first person to find and report a particular fact has not created the fact; he or she has merely discovered its existence. To borrow from Burrow-Giles, one who discovers a fact is not its "maker" or "originator."52

Proceeding from this foundation, the Court then turned to the question of whether originality, and thus the constitutionally necessary authorship, could be found in compilations of data. The Court confirmed the use of selection and arrangement as the basis for originality in a compilation of data in these terms:

The compilation author typically chooses which facts to include, in what order to place them, and how to arrange the collected data so that they may be used effectively by readers. These choices as to selection and arrangement, so long as they are made independently by the compiler and entail a minimal degree of creativity, are sufficiently original that Congress may protect such compilations through the copyright laws. Thus, even a directory that contains absolutely no protectible written expression, only facts, meets the constitutional minimum for copyright protection if it features an original selection or arrangement. ${ }^{53}$

The Court then spelled out the limits of protection afforded to such authorship:

This protection is subject to an important limitation. The mere fact that a work is copyrighted does not mean that every element of the work may be protected. Originality remains the sine qua non of copyright; accordingly, copyright protection may extend only to those components of a work that are original to the author. Thus, if the compilation author clothes facts with an original collocation of words, he or she may be able to claim a copyright in this written expression. Others may copy the underlying facts from the publication, but not the precise words used to present them .... Where the compilation author adds no written expression but rather lets the facts speak for themselves, the expressive element is more elusive. The only conceivable expression is the manner in which the compiler has selected and arranged the facts. Thus, if the selection and arrangement are original, these elements of the work are eligible for copyright protection. No matter how original the format, however, the facts themselves do not become original through association. ${ }^{54}$

48. 100 US 82 (1879). See note 16 and accompanying text.

49. 111 US 53 (1884). See also note 19 and text accompanying notes 16-18.

50. Feist, $111 \mathrm{~S} \mathrm{Ct}$ at 1288 . It is hard to be more explicit than the Court's blunt statement:

"Originality is a constitutional requirement."

51. Id, quoting Burrow-Giles, 111 US at 58

52. Id.

53. Id at 1289 (citations omitted).

54. Id (citations omitted). 
Thus the Court resolved the "undeniable tension" it had noted between the absence of protection for facts and the protection accorded to some compilations of facts in the following holding:

Facts, whether alone or as part of a compilation, are not original and therefore may not be copyrighted. A factual compilation is eligible for copyright if it features an original selection or arrangement of facts, but the copyright is limited to the particular selection or arrangement. In no event may copyright extend to the facts themselves. ${ }^{55}$

Turning to the copyrightability of compilations of uncopyrightable facts, the Supreme Court found that the requisite originality to support copyright protection could only be found in the selection and arrangement of the facts. ${ }^{56}$ For a compilation of data to be original, the Court "require[d] only that the author make the selection or arrangement independently ... and that it display some minimal level of creativity." 57 Although the Court was of the opinion that "the vast majority of compilations will pass this test," it noted that " $[t]$ here remains a narrow category of works in which the creative spark is utterly lacking or so trivial as to be virtually nonexistent. Such works are incapable of sustaining a valid copyright." 58

The Court then examined the Copyright Act and its legislative history on this issue, finding that they too denied copyright protection to facts per se. Similarly, a review of the definition of a compilation in the 1976 Copyright Act, with its explicit requirement of originality in the selection, coordination, and arrangement of its elements, ${ }^{59}$ and its legislative history, also led the Court to conclude that the Act deliberately rejected the "sweat of the brow" theory. ${ }^{60}$

The Court acknowledged that this permitted a later user of facts taken from a compilation to take advantage of the investment of effort and money made by the compiler, but held that such practices were part of the

55. Id at 1290. The Court explicitly analyzed the "sweat of the brow" test at some length, concluding that it was incompatible with the requirement of originality. Id at 1291-92. The Court suggested that the requirement of originality for compilations, while implicit in the 1909 Copyright Act, was not entirely clear, and had subsequently been misunderstood by some later courts.

56. Id at 1289 ("Where the compilation author adds no written expression but rather lets the facts speak for themselves, the expressive element is more elusive. The only conceivable expression is the manner in which the compiler has selected and arranged the facts.").

57. Id at 1294 .

58. Id (citation omitted).

59. The Copyright Act provides:

A "compilation" is a work formed by the collection and assembling of preexisting materials or of data that are selected, coordinated, or arranged in such a way that the resulting work as a whole constitutes an original work of authorship. The term "compilation" includes collective works.

17 USC \$ 101 (definition of "compilation").

60. Feist, $111 \mathrm{~S} \mathrm{Ct}$ at $1292-94$. The Court also made the argument that section 103(b), by extending the copyright in a compilation "only to the material contributed by the author of such work, as distinguished from the preexisting material employed in the work," meant that the owner of the copyright in a factual compilation could not "keep others from using the facts or data he or she has collected." Id at 1295.

Had the Court delved a little deeper into the legislative history, and noted the controversy surrounding the rejection of usage of the word "creativity" as part of the statutory definition of originality, see note 77 and text accompanying notes 76-77, the opinion might have either avoided the use of the word "creativity" or been more careful to indicate a precise meaning. 
constitutional scheme for copyright. The Court clearly derived this position from its view of the copyright-patent clause of the Constitution:

It may seem unfair that much of the fruit of the compiler's labor may be used by others without compensation. As Justice Brennan has correctly observed, however, this is not "some unforeseen byproduct of a statutory scheme." It is, rather, "the essence of copyright," and a constitutional requirement. The primary objective of copyright is not to reward the labor of authors, but "[t]o promote the Progress of Science and useful Arts." To this end, copyright assures authors the right to their original expression, but encourages others to build freely upon the ideas and information conveyed by a work. This principle, known as the idea/expression or fact/expression dichotomy, applies to all works of authorship. As applied to a factual compilation, assuming the absence of original written expression, only the compiler's selection and arrangement may be protected; the raw facts may be copied at will. This result is neither unfair nor unfortunate. It is the means by which copyright advances the progress of science and art ${ }^{61}$

The Court then decided whether the alphabetical listing of subscribers contained the requisite level of originality to support a copyright. Under the Court's analysis, the names, towns and telephone numbers were ineligible for protection per se as these were preexisting facts rather than the products of authorship. ${ }^{62}$ On the the issue of whether an alphabetical telephone directory displayed the necessary originality, the Court stated:

The question that remains is whether Rural selected, coordinated, or arranged these uncopyrightable facts in an original way. As mentioned, originality is not a stringent standard; it does not require that facts be presented in an innovative or surprising way. It is equally true, however, that the selection and arrangement of facts cannot be so mechanical or routine as to require no creativity whatsoever. The standard of originality is low, but it does exist ... . As this Court has explained, the Constitution mandates some minimal degree of creativity, and an author who claims infringement must prove "the existence of . . . intellectual production, of thought, and conception." 63

Characterizing the directory as "a garden-variety white pages directory, devoid of even the slightest trace of creativity," 64 the Court held that the selection, coordination, and arrangement of the names, towns, and telephone numbers of telephone subscribers did not exhibit the minimal level of originality needed to satisfy the constitutional standard for copyright protection. ${ }^{65}$ The originality of the copied entries was evaluated in the following terms:

Rural's selection of listings could not be more obvious: it publishes the most basic information-name, town, and telephone number-about each person who applies to it for telephone service. This is "selection" of a sort, but it lacks the modicum of creativity necessary to transform mere selection into copyrightable expression. Rural expended sufficient effort to make the white pages directory useful, but insufficient creativity to make it original. ${ }^{66}$

61. Feist, $111 \mathrm{~S} \mathrm{Ct}$ at $1289-90$ (citations omitted).

62. Id at 1296 .

63. Id, quoting Burrow-Giles, 111 US at 59-60 (other citations omitted).

64. Id at 1296 .

65. Id.

66. Id. 
Any claim to originality in the coordination and arrangement of the data was also rejected. Noting that the copied portions of the directory did nothing more than list telephone subscribers in alphabetical order, the Court stated:

This arrangement may, technically speaking, owe its origin to Rural; no one disputes that Rural undertook the task of alphabetizing the names itself. But there is nothing remotely creative about arranging names alphabetically in a white pages directory. It is an age-old practice, firmly rooted in tradition and so commonplace that it has come to be expected as a matter of course. It is not only unoriginal, it is practically inevitable. This time-honored tradition does not possess the minimal creative spark required by the Copyright Act and the Constitution. ${ }^{67}$

\section{III}

\section{Originality and Creativity After Feist}

\section{A. The Constitutional Basis for the Originality Requirement}

Feist squarely holds that the requirement of originality is imposed by the Constitution rather than being a mere statutory condition that can be diminished or abolished by legislation. ${ }^{68}$ This holding is clearly consistent with the precedents of Burrow-Giles Lithographic Co. $v$. Sarony, ${ }^{69}$ which derived the requirement of originality from the constitutional limitation of copyright to "Writings" of "Authors," 70 and The Trade-Mark Cases, ${ }^{71}$ which insisted that a work must be original to be regarded as a constitutionally recognized "writing."72 Feist, however, goes a step further, and says that not only is independent origination part of the constitutional requirement for originality, but the component of creativity is also constitutionally mandated. ${ }^{73}$ This holding should effectively bar any efforts by Congress to reverse the Feist decision legislatively by rewriting the copyright laws to protect unoriginal data compilations. Moreover, it would prevent a legislative return to the "sweat of the brow" as the standard for originality.

\section{B. Creativity as Part of the Originality Calculus}

The most important consequence of Feist is that it has interjected a distinct inquiry concerning creativity into the originality equation. In addition to the traditional originality inquiry into whether a work was independently originated, there must also be a determination that whatever was independently originated was sufficiently creative to satisfy Feist. Equally as important, Feist holds this two-step analysis for issues of originality is constitutionally mandated.

67. Id at 1297 (citation omitted).

68. See note 41 and accompanying text.

69. Burrow-Giles, 111 US at 58.

70. See text accompanying notes 19-21.

71. 100 US 82 (1879); see note 16 .

72. See text accompanying notes 17-18.

73. "[T]he Constitution mandates some minimal degree of creativity." Feist, $111 \mathrm{~S} \mathrm{Ct}$ at 1296. 
The formulations of the standard for originality prior to Feist required little more than independent effort, ${ }^{74}$ and certainly did not seem to incorporate a standard of creativity. Congress had explicitly stated that the "standard [of originality] does not include requirements of novelty, ingenuity, or esthetic merit, and there is no intention to enlarge the standard of copyright protection to require them." 75 Moreover, during the protracted statutory revision process that led to the current Copyright Act, the Register of Copyrights originally took the position, that to be copyrighted, a work must be original (independently originated) and "must represent an appreciable amount of creative authorship."76 However, this position was the subject of a good deal of criticism and was subsequently abandoned by the Register of Copyrights. ${ }^{77}$ In light of these legislative and judicial pronouncements, it is perhaps understandable why the addition of "creativity" into the standard for originality comes as something of a surprise.

The obvious issue is what is required to satisfy the element of "creativity" that the Feist opinion interjects. Feist itself does not promulgate a definition or a test for determining creativity. But the following passage affords a useful insight into what the Supreme Court had in mind:

$[T]$ he originality requirement is not particularly stringent. A compiler may settle upon a selection or arrangement that others have used; novelty is not required. Originality requires only that the author make the selection or arrangement independently (i.e., without copying that selection or arrangement from another work), and that it display some minimal level of creativity. Presumably, the vast majority of compilations will pass this test, but not all will. There remains a narrow category of works in which the

74. In a frequently quoted passage from his influential opinion in Alfred Bell $\xi$ Co. $v$. Catalda Fine Arts, Inc., 191 F2d 99, 103 (2d Cir 1951), quoting Hoague-Sprague Corp. v Frank C. Meyer Co., 31 F2d 583, 586 (EDNY 1929), Judge Jerome Frank stated: "Originality in this context 'means little more than a prohibition of actual copying.' ' See also Tennessee Fabricating Co. v Moultrie Manufacturing Co., 421 F2d 279, $281-82$ (5th Cir 1970); note 26.

75. HR 1476 at 51 ; S Rep No 473 at 50 (both cited in note 8 ).

76. Report of the Register of Copyrights on the General Revision of the U.S. Copyright Law, House Committee on the Judiciary, 87th Cong, Ist Sess 9 (Committee Print, 1961).

77. Explaining the adoption of the phrase "original works of authorship" in section 102(a) of the 1965 Copyright Revision Bill, S 1006, 89th Cong, lst Sess (1965); HR 4347, 89th Cong, lst Sess (1965), the Supplementary Report of the Register of Copyrights on the General Revision of the U.S. Copyright Law stated:

[W] hen it came to drafting, a great deal of concern was expressed about the dangers of using a word like "creative" in this context. It was argued that the word might lead courts to establish a higher standard of copyrightability than that now existing under the decisions, and that any effort to define "original" could bring about the same undesirable result.

In recognition of these arguments, section 102 of the bill specifies the subject matter of copyright simply as "original works of authorship," without further attempts at definition. Our intention here is to maintain the established standards of originality without implying any further requirements of aesthetic value, novelty, or ingenuity.

Supplementary Report of the Register of Copyrights on the General Revision of the US Copyright Law: 1965 Revision Bill, House Committee on the Judiciary, 89th Cong lst Sess 3 (Committee Print, 1965).

The language of "original works of authorship" was thereafter carried forward without change into subsequent copyright revision bills, culminating with the adoption of the 1976 General Revision of Copyright Act. See Pub L No 94-553, tit I, §§ 101, 102(a), 90 Stat 2541, 2544-45 (1976), codified at 17 USC $\& 102(a)$ (1988). 
creative spark is utterly lacking or so trivial as to be virtually nonexistent. . . . Such works are incapable of sustaining a valid copyright. ${ }^{78}$

Clearly; the Court does not see itself as producing a wholesale invalidation of copyright protection of compilations and databases; it only invalidates those whose creativity in the selection, coordination and arrangement of facts is so minimal as to be virtually nonexistent.

Further insight may be gleaned from the Court's discussion of why an alphabetical list of telephone subscribers from a contiguous geographic area fails to satisfy the creativity component of the originality requirement. ${ }^{79}$ Scattered over a series of paragraphs, the Court recites a litany of characteristics of a typical white pages directory that fails to qualify as creative: It is a work "in which the creative spark is utterly lacking or so trivial as to be virtually nonexistent," 80 "so mechanical or routine as to require no creativity whatsoever," 81 "garden variety," 82 "devoid of even the slightest trace of creativity," 83 a work whose selection, coordination and arrangement "could not be more obvious," 84 and about which "there is nothing remotely creative," 85 but consists of "an age-old practice, firmly rooted in tradition and so commonplace that it has come to be expected as a matter of course," 86 "not only unoriginal, it is practically inevitable," 87 a "time-honored tradition [that] does not possess the minimal creative spark required by the Copyright Act and the Constitution." 88 Although definition by negative examples is usually treacherous, the Court's repeated examples provide a relatively consistent theme that ultimately suggests a coherent limit for the creativity component of originality.

There are fewer positive formulations of creativity in the Feist opinion. Referring back to Burrow-Giles, the Court stated that "an author who claims infringement must prove 'the existence of . . . intellectual production, of thought, of conception." "89 Taking this statement together with the more plentiful negative descriptions, two suggestions can be made. First, the Court seems to be driving at the notion that just as there can be a public domain for other materials there can also be a public domain for the structure or formats of factual compilations. This notion is palatable either because the structure is often so elementary or screamingly obvious that we do not want anyone to be able to claim a monopoly, or because it is such a cultural cliché that we

78. Feist, $111 \mathrm{~S} \mathrm{Ct}$ at 1294 (citation omitted).

79. The Court also mentioned, but did not rely on, the argument that the plaintiff did not "select" the data published in its directories, but was compelled to do so by the state law that created its monopoly. Id at 1296-97.

80. Id at 1294 .

81. Id at 1296.

82. Id.

83. Id.

84. Id.

85. Id at 1297 .

86. Id.

87. Id.

88. Id.

89. Id at 1296, quoting Burrow-Giles, 111 US at 59-60 
instinctively reject the idea that anyone claiming a copyright for the structure actually originated it. Viewed in this way, an alphabetical listing of telephone subscribers is merely the insertion of uncopyrightable facts into an unoriginal structure. Regardless of how recently the facts were discovered or how difficult they were to find, they can never be copyrighted.90 Once the proposition that all facts are inherently uncopyrightable is clearly recognized, then it follows fairly logically that inserting these elements into a structure that is derivative to the point of being an almost automatic reaction is simply not going to be original.

Second, the Court seems to be insisting that there must be some injection of independent aesthetic or artistic judgment in the decisions concerning the selection, coordination, or arrangement of the facts in a compilation for it to possess the requisite "minimum level" of creativity. In this sense, there is a parallel to be drawn to the Bleistein decision," ${ }^{11}$ which regarded "the personal reaction of an individual upon nature," or expression of the author's "unique" personality as the key to satisfying the constitutional requirement of originality. ${ }^{92}$ According to this line of analysis, the inclusion, exclusion, and order of presentation of data will be deemed sufficiently creative if it reflects some personal reaction to or personal analysis of the data, rather than merely fitting facts into obvious, pre-existing formats. Although it is not explicitly articulated by the Feist opinion, in this sense the case's result seems to parallel the functionality limitations imposed by section 102(b) of the Copyright Act. Listing the names of telephone subscribers in alphabetical order is obvious not only because of the ages-old utilization of this format for listing names and accompanying data, but also because it is the obvious functional and conventional answer to the question of what are the accepted standard formats for listing data of this type.

Although the definition of creativity in Feist is more descriptive than explanatory, it is clear that creativity, as a term of art in copyright law, like originality, is pegged at the lower end if not the bottom of the spectrum of its wide-ranging common usage. Creativity most definitely is a lower standard than novelty, and to be creative, the selection, arrangement and presentation of facts need not be either "innovative or surprising."93 In short, creativity, according to Feist, need not be very creative after all, although it must be more than independent effort and expense in doing what is obvious.

Minimal though it may be, however, the creativity component of the originality requirement serves the purpose for which the Court intended it: It

90. Some discovered facts may be eligible for patent protection if their discoverer can use them in a technology or incorporate them into a physical form that will qualify for protection under the Patent Act. Discovered facts can be kept secret, and some of their economic value can be protected through the law of trade secrets.

91. See text accompanying notes 22-25.

92. Bleistein, 188 US 239, 250 (1903).

93. Feist, $111 \mathrm{~S} \mathrm{Ct}$ at 1296. 
places the completely obvious and "practically inevitable" arrangements of facts and public domain materials outside the reach of copyright. ${ }^{94}$

\section{Methodology of the Originality Inquiry}

The structure of the Feist opinion indicates that when determining the question of originality, the selection of the facts to be compiled, and the arrangement and presentation of those facts, must be separately evaluated. The opinion discusses "Rural's selection of listings," and concludes that " $[\mathrm{t}] \mathrm{his}$ is 'selection' of a sort, but it lacks the modicum of creativity necessary to transform mere selection into copyrightable expression."95 It treats selection as a distinct issue, with the clear implication that if the requisite originality were found in the selection of the data, then the directory would be copyrightable regardless of the originality or lack thereof in the coordination and arrangement of the data. Having concluded that the selection lacked originality, Feist then decided that "Rural [cannot] claim originality in its coordination and arrangement of facts," 96 because "there is nothing remotely creative about arranging names alphabetically in a white pages directory." 97 This treatment of a compilation's coordination and arrangement as an independent source of the requisite originality for copyrightability indicates that originality in either the selection or the coordination and arrangement can make a database copyrightable. ${ }^{98}$

Certainly one of the results Feist imposes on future courts is that placing an obvious grouping of data in a common and obvious format will not be copyrightable. Such items as an alphabetical list of telephone subscribers, a chronological list of American presidents, a numerical list of zip code areas, a list of states in order of population size or date of admission to the Union, baseball players by batting average, home runs, or RBIs, and the like simply will not qualify.

There are some interesting consequences that follow from this division of the search for creativity into two inquiries (one into creativity in selection and the other into creativity in coordination and arrangement). When a data compilation includes all items of a defined class, can there possibly be originality? For example, a compilation may include all written opinions of the United States federal courts. Does the decision to select all cases as opposed to selected cases negate originality as to the selection? If so, this

94. It also makes even clearer the fallacy of the already specious argument that a copy of a work produced by different effort, expense, and instigation than that leading to the physical production of the copied work can claim to be original because the effort and expense of making the copy were independent of those involved in making the copied work.

95. Feist, $111 \mathrm{~S} \mathrm{Ct}$ at 1296.

96. Id at 1297 .

97. Id

98. It is not clear what the difference is between the coordination of data and the arrangement of data, although the Copyright Act speaks of these elements as if there were a significant difference between them. 17 USC $\S 101$ ("A 'compilation' is a work formed by the collection and assembling of preexisting materials or of data that are selected, coordinated, or arranged in such a way that the resulting work as a whole constitutes an original work of authorship."). 
selection may create a difficult problem for suppliers of data, particularly in the form of electronic databases, because their commercial value may depend upon their completeness, even though they may lose copyright protection precisely by being complete.

Conversely, selection of some rather than all of the members of a category of data may well show the necessary originality. Staying with the example of judicial opinions, West Publishing Company, the preeminent reporter of court decisions in the United States, publishes only roughly 25 percent of the judicial opinions written each year by the courts in its National Reporter System.99 West exercises some independent judgment in choosing which opinions it will print and which it will leave unpublished. While the recommendation of the judges as to whether an opinion will be published or unpublished is normally determinative, recommendations of both types have been ignored by West. ${ }^{100}$ If this selectivity on the part of West embodies the "modicum of creativity"101 that Feist requires, ${ }^{102}$ then Feist would not change the finding of copyrightability for West Publishing Company's National Reporter System in West Publishing Co. v. Mead Data Central, Inc., ${ }^{103}$ which granted a preliminary injunction against the use of "star pagination"104 of cases reported in West's National Reporter System. ${ }^{105}$ Because West's independent judgments in deciding which cases to report makes it rather unlikely that another compiler of a national reporting system would select the identical set of opinions to be published, West's selections would arguably fit within the notion of an independent exercise of judgment that establishes the creativity standard of Feist.

99. The Supreme Court Reporter is the one exception, publishing all opinions issued by the United States Supreme Court, as is done by the United States Reports, Lawyer's Edition, and United States Law Week. For the other units in West's National Reporter System, the percentage may vary. For example, it is estimated that approximately $10 \%$ of the opinions authored by the federal district courts are published, while roughly $40 \%$ of the opinions authored by the federal courts of appeal are published.

100. Telephone interview with Vance Opperman, of Opperman, Heins \& Paquin, Minneapolis, Minnesota (Spring 1990), counsel for West Publishing Company in West Publishing Co. $v$ Mead Data Central, Inc., 799 F2d 1219 (8th Cir 1986).

101. Feist, $111 \mathrm{~S}$ Ct at 1288.

102. Given West's use of some independent judgment in deciding which cases to report, it is rather unlikely that another compiler of a national reporting system would select the identical set of opinions to be published, although the great majority of such decisions would overlap.

103. 616 F Supp 1571 (D Minn 1985) (preliminary injunction granted), aff'd, 799 F2d 1219 (8th Cir 1986). The case was settled before reaching a final trial court decision. The decision and the settlement are discussed at some length in Patterson \& Joyce, 36 UCLA L Rev at 719 (cited in note 8).

104. "Star pagination" consists of inserting asterisks and page numbers into the text of cases reported in the LEXIS and WestLaw databases which indicate the location and page number of the page breaks in the text of those cases as reported in the West National Reporter System.

105. In post-Feist terminology, there is nothing original in numbering pages in consecutive numerical order. However, the data (cases) that West arranged were subject to some degree of selectivity on West's part rather than using all cases or following judicial preferences. Moreover, West chose the courts to be reported and the order in which cases were reported in each unit of the National Reporter System, thus providing some degree of coordination and arrangement. Whether a later court would characterize the parameters chosen by West for coordinating and arranging cases as sufficiently creative is a distinct issue from that of the selection of the cases to report. 
Another question is whether a standard form of ordering data applied to unlikely data would be original, even if the data itself would be quite ordinary in a different format. In other words, could an unusual combination of commonplace data, coordinated and arranged in a commonplace way, be considered original when the data and the method as a combination seem unusual or even creative? For example, listing all copyright decisions of the United States courts alphabetically by the last name of the judge writing the opinion uses obvious and commonplace data, at least to copyright lawyers and scholars, ${ }^{106}$ and arranges it in an obvious and commonplace method. However, the combination of this data arranged in this order strikes one as a bit unusual. Perhaps this is because, while it is conceivable somebody would be interested in this data arranged in this order, it is simply unlikely to be at all useful to many people. Nonetheless, does the limited utility of such an arrangement militate against a finding of originality? Does the fact that the existing databases of Lexis and Westlaw would permit you to sort the relevant cases into this order, albeit with additional effort, downgrade the creativity involved?

A more extreme example would be the arrangement of judicial opinions by the date of investiture of the authoring judge. Here it is hard to see what the utility of such a compilation would be, thus making it easier for the compiler of such a database to claim that it involved personal and even fanciful judgments to provide the requisite creativity for constitutional authorship. Given the infrequency of demand for such combinations, however, the problem may remain one that is purely theoretical.

IV

\section{The Application of FEIST}

Even though it is barely four months old at this writing, ${ }^{107}$ Feist has already been an important focus in numerous subsequent cases. A number of the decisions have applied Feist to cases involving compilations of data selected or presented in ways that would arguably satisfy the originality requirement. ${ }^{108}$

106. Both Copyright Decisions published by the United States Government Printing Office and Copyright Law Decisions published by Commerce Clearing House purport to report all or nearly all written opinions in copyright law cases decided in American courts, although the CCH reports do not begin until 1978. Both the West National Reporter System and the United States Patents Quarterly publish copyright decisions from many different American courts, but both of these reporters exercise greater discretion in omitting opinions.

107. The Supreme Court's opinion in Feist was issued on March 27, 1991.

108. Some of the decisions were very obvious in light of $F$ eist and require no extended comment. In Illinois Bell Telephone Co. v. Haines E Co., 744 F Supp 815 (ND Ill 1989), aff'd, 905 F2d 1081 (7th Cir 1990), vacated and remanded, 111 S Ct 1408 (1991), a case with nearly identical facts, the Supreme Court vacated and remanded for further consideration a judgment favoring the publisher of another white pages directory on the basis of Feist. On remand, the court of appeals ordered judgment in favor of the alleged infringer. 932 F2d 610 (7th Cir 1991). Similarly, in Dun E Bradstreet, Inc. $v$. Walter (1991 WL 78172) (ND Ill May 7, 1991), a case involving infringement of copyrighted business data compiled for direct marketing campaigns (the names and mailing addresses of businesses and the names of their chief executives), the plaintiff voluntarily dismissed its copyright claim with prejudice in light of the Feist decision. 
In particular, cases from the Second and Eleventh Circuits not only represent applications of Feist to different types of factual compilations, but also may provide extremely influential watersheds in the future application of Feist. The approaches of these two cases are distinctly at odds with each other; even though their results might be rationalized. This choice of approaches could be the critical dispositive element in subsequent cases.

\section{A. Kregos v. Associated Press}

A more difficult question was presented by Kregos v. Associated Press, 109 which is perhaps the cutting-edge decision in the aftermath of Feist. In Kregos, the plaintiff designed a form for displaying statistical information about the opposing pitchers in upcoming baseball games. The categories of information were arranged vertically with the teams for each game in the coming day listed in two horizontal rows, with the visiting team above the home team. The categories included the following: (1) the names of the opposing teams; (2) the probable starting pitchers and whether they were left or right handed; (3) the starting time of the game; (4) the betting odds on the game; (5) the pitcher's won-lost record and earned run average for the current season; (6) a category called "vs. team at site," which included the pitcher's won-lost record, total number of innings pitched, and earned run average against that opponent at that playing venue for the current season; (7) a category called "last 3 starts," which included the pitcher's won-lost record, total number of innings pitched, and earned run average based on his last three starting assignments; and (8) a category entitled "MBA," an abbreviation for "men on base average," the average number of men allowed to reach base via hits and walks per nine innings pitched. ${ }^{110}$ After Kregos began publishing his form, the Associated Press began to distribute an essentially identical form that contained only cosmetic differences. ${ }^{111}$ In a decision pre-dating Feist, the trial court held that plaintiff's forms lacked the requisite originality to be copyrightable, ${ }^{112}$ and, as alternate grounds, that idea and expression were merged in plaintiff's forms and thus not protected

109. 937 F2d 700 (2d Cir 1991), aff'g in part and rev'g in part $731 \mathrm{~F}$ Supp 113 (SDNY 1990).

110. Copies of the various charts at issue in Kregos are attached to the trial court opinion as appendices 1-4. See 731 F Supp at 122-24. For purposes of its analysis, the Second Circuit regarded the "MBA" category as part of the "last 3 starts" category, although it does not appear to be a subset of that category from the charts. Compare 937 F2d at 702 with 731 F Supp at 122 (appendix 1).

111. For example, the heading "Odds" in the Kregos form was labeled "Line" in the Associated Press form, and the heading "MBA" (men on base average) in the Kregos form was labeled "AHWG" (average hits and walks per game) in the Associated Press form.

112. Kregos, 731 F Supp at 117-18. 
by copyright, 113 and that plaintiff's forms also fell within the "blank forms" doctrine. ${ }^{114}$

The Second Circuit began its opinion by comparing Kregos' forms with prior attempts to compile similar data.115 The court noted "that prior to Kregos' 1983 form, no form had listed the same nine items collected in his form," 116 and that "[i]n the earlier forms ... the few items common to Kregos' form were grouped with items different from those in Kregos' form." 117 Of the prior forms that were in evidence, none contained more than three of Kregos' nine items, and the item of men on base average in recent starts had never appeared previously in any other form. ${ }^{118}$

After synopsizing the reasoning and import of Feist, which had been decided about three months earlier, the Second Circuit came to the obvious conclusion that "as to compilations of facts, independent creation as to selection and arrangement will not assure copyright protection; the requirement of minimal creativity becomes an important ingredient of the test for copyright entitlement." 119 It is important to note that the Second Circuit broke the originality inquiry down into two separate questions. The first issue was the question of originality in the more traditional sense of independent origination, else the work would be regarded as copied or plagiarized and thus not the copyrightable production of an author. The second issue, creativity, was dealt with as a separate question. To the Second Circuit, at least, these are two distinct issues, and both must be addressed.

The Second Circuit's use of prior art in its inquiry into originality and creativity, in this case earlier forms of pitching statistics, is also of note. The

113. Id at 119-20. The merger doctrine, a corollary of the idea-expression distinction, provides that if there are limited ways to express a particular idea, then the idea and expression are deemed to merge. Because copyright cannot protect ideas, 17 USC $\$ 102(b)$, copyright protection is denied to such expression. See Morrissey v Procter $\mathcal{E}$ Gamble Co., 379 F2d 675 (1st Cir 1967); Matthew Bender $\mathcal{E}$ Co. v Kluwer Law Book Publishers, 672 F Supp 107, 109 (SDNY 1987). This doctrine has its roots in Baker v. Selden, 101 US 99 (1879). See generally Abrams, The Law of Copyright \$ 3.03[B][2] (cited in note 3).

114. Kregos, 731 F Supp at 120-21. This doctrine has its roots in Baker v. Selden, 101 US 99 (1879), and prevents the copyrighting of a "blank form" that is merely used to record information. The regulations promulgated by the Register of Copyrights codify this doctrine. 37 CFR $\$ 202.1$ (c). See generally Abrams, The Law of Copyright $\S 203.03$ [B][3] (cited in note 3).

115. This was not done out of concern for a novelty standard, but to lay to rest any contention that Kregos' form was itself copied rather than original to Kregos.

116. The court ignored the information concerning the teams, the names of the pitchers and their records, the starting times and the probable odds, stating "there can be no claim of a protectable interest in the categories of information concerning each day's game." Kregos, 937 F2d at 702. The "nine items" the Second Circuit was concerned with were (1) the pitcher's won-lost record for the current season, (2) the earned run average for the current season, (3) the current season won-lost record against that opponent at that particular site, (4) the innings pitched against that opponent at that particular site for the current season, (5) the current season won-lost record against that opponent at that particular site, (6) the pitcher's won-lost record in his last three starts, (7) the innings pitched in the pitcher's last three starts, (8) the pitcher's earned run average in his last three starts, and (9) the average men on base allowed by hits or walks per nine innings pitched.

117. $937 \mathrm{~F} 2 \mathrm{~d}$ at 702 .

118. Id. The closest prior resemblance was a weekly statistical form that gave a pitcher's average men on base over the course of an entire season.

119. Id at 704 . 
similarity of Kregos' form to previously published forms goes to both the issues of independent origination and creativity. If Kregos' form was identical to a prior form or varied from it by only a trivial degree, this would raise the question of whether Kregos had originated his form independently. Such similarity would not necessarily be conclusive, as Kregos might still be able to persuade the trier of fact that he had not copied from the similar form and the similarities were merely coincidental. However, because of the similarities, "the issue would then arise as to whether the previously published selections of statistics had reached the point where it could be said that Kregos' selection was insufficiently creative, or in the words of Feist, 'entirely typical,' 'gardenvariety,' or 'obvious.' "'120

On the issue of independent origination, the Second Circuit stressed the point that " $[t]$ he universe of known facts available only from inspection of box scores of prior games is considerably greater than nine," 121 the number of facts that Kregos had selected for his form. The court illustrated its point by giving examples of statistics that could have been reported to show that many different statistics could be generated by manipulating the basic information from the box score. The court concluded that "there are at least scores of available statistics about pitching performance available to be calculated from the underlying data and therefore thousands of combinations of data that a selector can choose to include in a pitching form."122 Reiterating that "the record discloses no prior pitching form with more than three of the pitching performance statistics that are included in Kregos' selection of nine statistics," 123 the Second Circuit concluded that Kregos' form was independently originated.

Turning to the question of creativity, the Second Circuit concluded that "[i]n view of the variety of pitching forms disclosed in the record, it is unlikely that such a conclusion could be reached and certainly could not be reached as a matter of law," 124 reversing the trial court's grant of summary judgment for the defendant on the issue of copyrightability. ${ }^{125}$ The Second Circuit seemed to adopt a test for future cases by posing the question "whether the previously published selections of statistics had reached the point where it could be said that Kregos' selection was insufficiently creative, or in the words of Feist, 'entirely typical,' 'garden-variety,' or 'obvious.'" 126 If so, then the selection and arrangement will lack the minimum creativity necessary for copyrightability; otherwise, the work will satisfy the creativity standard of

120. Id at 705 .

121. Id at 704

122. Id. The court noted "[i]f the universe of available data included even 20 items and a selector was limited to 9 items, there would be 157,960 combinations of items available." Id at $704 \mathrm{n} 3$.

123. Id at 705 .

124. Id.

125. The existence of an essentially identical prior form could also affect the determination of whether the defendant had copied from the prior form in which Kregos had no copyright rather than from Kregos' form.

126. Kregos, 937 F2d at 705. 
Kregos. This conforms the standard to the "minimal degree of creativity" 127 or "minimal level of creativity" 128 required by Feist, and, consistent with Feist, would deny copyrightability to only those "works in which the creative spark is so utterly lacking or so trivial as to be virtually nonexistent."129

Kregos provides some elaboration of the creativity component of the originality standard articulated by Feist. Feist does not really tell us what the standard for creativity is, only that a selection and arrangement of facts that is "entirely typical," "garden-variety," or "obvious" will not satisfy it. Feist only decided that an alphabetical arrangement of names was not sufficiently creative to be original, leaving it to later courts in subsequent cases to make the arguably more difficult judgments of the requisite degree and nature of creativity that would satisfy the originality standard. Kregos uses these terms from Feist as the test for creativity, suggesting that any work of authorship which can be said to exceed these minimal standards will be sufficiently creative to support a copyright. In sum, while Feist tells us the negative, that a work failing to exceed these minima is not copyrightable, Kregos provides the positive, that any work exceeding these minima is sufficiently creative to be copyrightable.

While the question of whether a compilation's selection and arrangement is "entirely typical," "garden-variety," or "obvious" is not a clear, bright-line test for creativity, it is nonetheless a tractable standard that probably can be applied with a reasonable degree of consistency. Moreover, this minimal standard of creativity is consistent with the traditional notions of originality as independent origination without regard to novelty or aesthetic merit, thus preserving the system of balances between the rights of authors, publishers, and the public that is incorporated into the Copyright Act. While it is perhaps too early to predict, Kregos may well turn out to be the crucial interpretation and implementation of Feist that will most influence later courts.

\section{B. BellSouth Advertising E Publishing Corp. v. Donnelly Information Publishing}

In BellSouth, ${ }^{130}$ the Eleventh Circuit confronted the issue of copying from a classified "yellow pages" directory. The trial court had granted summary judgment for the plaintiff BAPCO on its copyright infringement claim prior to the Feist decision. ${ }^{131}$ The Eleventh Circuit acknowledged that Feist had disapproved the "sweat of the brow" standard and concluded, as a consequence, that "the information contained in the directory which is accumulated by effort or labor does not lie within the hegemony of BAPCO's

127. Feist, $111 \mathrm{~S} \mathrm{Ct}$ at $1287,1289,1296$.

128. Id at 1294 .

129. Id.

130. 933 F2d 952 (11th Cir 1991).

131. BellSouth Advertising $\mathcal{E}$ Publishing Corp. $v$ Donnelly Information Publishing, Inc., 719 F Supp 1551 (SD Fla 1988). 
copyright."132 Based on the statutory definition of a compilation, ${ }^{133}$ the court then stated that copyright would protect the (1) selection, (2) coordination, and (3) arrangement of data in a compilation. From this, the court drew the conclusion that copyright protects only the "format" of a compilation, stating:

[C]opyright protection only extends to the selection, coordination and arrangement which comprises an original format of the compilation work. In the case of compilations, to satisfy the second element of the copyright infringement cause of action, there must be a substantial appropriation of the original format of the compilation to constitute the copying of protected material. Accordingly, we must determine whether there was a substantial appropriation of the format of the plaintiff's compilation. ${ }^{134}$

Having designated the "format" as the element that copyright law would protect in an eligible compilation, the opinion then addressed whether the format of BAPCO's yellow pages was original. The court enumerated a number of selections in the compilation's creation: (1) the geographic boundaries for each directory, which determined which businesses would be listed in each directory; (2) the closing date for the directory, which excluded subsequent modifications to the information and effectively froze the directory's contents; and (3) the classifications of listed businesses, created or selected by BAPCO so that each listing could be placed in an appropriate classification. ${ }^{195}$

On the issue of coordination, the court observed that "BAPCO had to coordinate all the current informational components of a particular business into one complete business listing. The name of the business had to be coordinated with the business' address and the business' phone number."136

As to the arrangement of the data, the opinion pointed out that the data were arranged both by business classification within each directory and by geographic area between directories. The court then summarily concluded that the yellow pages were original:

These acts of selection, coordination and arrangement contribute to produce what we agree to be an original format of the directory. The format of the Yellow Pages before us is sufficiently distinct from the "white pages" phone directory involved in Feist to meet the minimal level of independent creativity required to qualify as original. The "white pages" format is a simple alphabetical listing of residential names, addresses and phone numbers. Because the Yellow Pages directory published by BAPCO

132. 933 F2d at 957 (footnote omitted).

Shortly thereafter, the opinion suggests that " $[t]$ he labor is more appropriately protected under the law of unfair competition." Id at $957 \mathrm{nll}$. This suggestion that some amorphous tort of unfair competition or misappropriation can protect a compilation that the copyright law finds to lack the threshold quantum of creativity necessary for copyright protection is very doubtful as such a claim would be preempted by the Copyright Act. See generally Howard B. Abrams, Copyright, Misappropriation, and Preemption: Constitutional and Statutory Limits of State Law Protection, 1983 S Ct Rev $509,559-66$.

133. "A 'compilation' is a work formed by the collection and assembling of preexisting materials or of data that are selected, coordinated, or arranged in such a way that the resulting work as a whole constitutes an original work of authorship." 17 USC $\$ 101$.

134. $933 \mathrm{~F} 2 \mathrm{~d}$ at 957 (emphasis in original; footnotes omitted).

135. Id.

136. Id at 957-58. 
provides a convenient, unique organization of business listings and advertisements, it merits originality. ${ }^{137}$

The opinion then addressed the issue of whether the protected elements of selection, coordination, and arrangement had been infringed and found that three separate acts of the defendant Donnelly constituted infringement. The first occurred when Donnelly typed data from the yellow pages directories into its computer and inserted a classification code which could be translated back into BAPCO's classification headings. Donnelly also inserted an advertising code which indicated the size of the advertising purchased by each business listed in the BAPCO directories. The Eleventh Circuit concluded that "[a]lthough these codes were authored by Donnelly, they correspond to the selection, coordination and arrangement authored by BAPCO" 138 and were therefore infringing.

The court also held that Donnelly infringed by printing this information on sales lead sheets for its advertising sales force. ${ }^{39}$ Although this information was arranged in tabular form on the sales lead sheets, and thus did not resemble BAPCO's directory entries, the court found that it still "appropriate[d] the coordination of informational components in a business listing and the selection of categories utilized by the [BAPCO] format."140 Finally, despite the insertion of additional advertisements, the deletion of others, and the differing layouts of the pages, the publication of Donnelly directories was regarded as an infringement because "the overall format of the Yellow Pages is substantially appropriated."141 The court rejected fair use defense ${ }^{142}$ and a copyright misuse defense. ${ }^{143}$

Any evaluation of the BellSouth opinion must separate the question of whether the determination of originality in plaintiff's yellow pages was correct, from the separate issue of whether BellSouth's doctrinal assertions and the focus of its originality inquiry are consistent with Feist. The classification system for BAPCO's directories may well be original, as it certainly involves choices of classifications and titles. However, this does not end the inquiry mandated by Feist. First of all, to be copyrightable, the classification system would have to be independently originated by BAPCO. To the extent that it is

137. Id at 958 .

138. Id at 959 .

139. The lead sheets contained the telephone number, business name, business address, business classification, advertising code, advertising rate, and identified in which of BellSouth's directories the business was listed. 933 F2d at 959.

140. Id. The court correctly pointed out that the statutory definition of a compilation in $\S 101$ of the Copyright Act referred to "data that are selected, coordinated, or arranged in such a way that the resulting work as a whole constitutes an original work of authorship." Because of the disjunctive "or," the court concluded that the copyright in a compilation could be infringed by copying any one of the three elements of selection, coordination, or arrangement even if the other elements were not copied.

141. Id.

142. Id.

143. Id at 960-61. 
not, BAPCO could not claim a copyright. This inquiry is not pursued in BellSouth. ${ }^{144}$

BellSouth also made no inquiry into whether the selected categories of business classifications were, in the language of Feist, "entirely typical," "garden-variety," or "obvious." Skimming any yellow pages directory selected at random makes a reasonably persuasive case for lack of creativity. Many of the classifications may be determined by factors outside of the publisher's realm of decision. For example, who can be listed as a lawyer is determined by whom the relevant jurisdiction has licensed to practice law, not by the telephone company. Moreover, it seems quite obvious that there must be separate categories for such persons and firms. Even though there may be a choice between calling them lawyers or attorneys, this choice may not amount to a display of the minimum level of creativity necessary for originality under Feist. The fact that the classifications are arranged in alphabetical order and that the individual entries are arranged alphabetically within each classification clearly fails to satisfy the creativity requirement of Feist. Although BellSouth rightly insists that the allegedly infringed directory be viewed as a whole rather than as a sum of separate individual choices, ${ }^{145}$ the issue of creativity is not laid to rest by that observation because the classification system, taken as a whole, may well be "entirely typical," "garden-variety," "obvious," or even "practically inevitable." The failure of the BellSouth opinion to explore this issue which seems mandated by Feist is disappointing at best, and dangerously out of touch with Feist at worst.

Some of the examples given by BellSouth as demonstrating the necessary originality in the selection, coordination, or arrangement of data in the directories are obviously inconsistent with Feist. For its example of originality, including the necessary creativity, in the coordination of data in the directory, the Eleventh Circuit states: "Secondly, BAPCO had to coordinate all the current informational components of a particular business into one complete business listing. The name of the business had to be coordinated with the business' address and the business' phone number." 146

To say the "coordination" of a telephone subscriber's name with its address and telephone number demonstrates originality under Feist is simply ludicrous. The directory at issue in Feist did precisely the same thing, coordinating the listing of the subscribers with their respective towns and telephone numbers. Simply because BAPCO's directory was limited to business subscribers and Rural Telephone's directory was not is not a rational

144. One obvious question is whether the classification system was simply the one previously used by AT\&T before the breakup of AT\&T into the "baby Bells." If so, what rights did AT\&T transfer to BellSouth? If the same rights were transferred to other "baby Bells," then BellSouth might well be a nonexclusive licensee and have no standing to sue for copyright infringement. 17 USC $\S 501$ (b). There is also the parallel question of how much of BellSouth's classification scheme was derived from other directories in which BellSouth had no claim to copyright ownership. These questions deserve an answer which is not forthcoming from the opinion.

145. 933 F2d at 959 n 18 .

146. Id at $957-58$. 
basis for calling BAPCO's coordination original in light of Feist's holding that Rural Telephone's was not. The selection of geographic boundaries for each directory was also present in Feist, where the Supreme Court held there was no originality; yet in BellSouth, the Eleventh Circuit cites it as an act of selection demonstrating the necessary originality for copyrightability. ${ }^{147}$ Indeed, except for the issue of categories of classification for their advertisers, every act of selection and arrangement cited by BellSouth as demonstrating originality was also present in Feist.

Moreover, BellSouth fails to make any inquiry into whether the directories exhibited the minimal level of creativity needed to satisfy the originality requirement as formulated by Feist. It makes no effort to identify anything that is explicitly creative within the directories, and fails to make any inquiry as to whether the elements of selection, coordination, and arrangement of the directories were "entirely typical," "garden-variety," "obvious," or even "practically inevitable." This failure raises serious questions about whether the reasoning of BellSouth is consistent with Feist, if not antagonistic to it. Finally, the overall tone of the BellSouth opinion suggests not only reluctance to abandon the "sweat of the brow" test, but also determination to limit Feist's abandonment of the test to white pages alphabetical directories. Thus BellSouth effectively writes "sweat of the brow" back into the law. ${ }^{148}$ Perhaps the best that can be hoped for is that BellSouth will be remembered only for the proposition that a classification system for listing businesses, if independently originated, may be sufficiently creative to be original and thus copyrightable, with the inquiry into originality and its creativity component left for determination on a case by case basis. Certainly, one hopes that the creativity issue will not be blithely ignored by later courts as it was in BellSouth.

\section{Other Cases}

1. Compilations. Several other interesting cases involving claims of copyright in compiled data have been decided since Feist, although none of them have the doctrinal or methodological implications for future courts of either Kregos or BellSouth. For the most part, these cases seem to be relatively straightforward applications of Feist to their particular fact patterns. ${ }^{149}$

Victor Lalli Enterprises v. Big Red Apple, Inc., ${ }^{150}$ a per curiam opinion of the Second Circuit, upheld a trial court's holding of insufficient originality to support a copyright claimed for "Val's Original Genuine Black Cat Weekly Card," a weekly compilation of numbers calculated from established formulas

147. Id at 957 .

148. "If Donnelley had been interested only in the [names, addresses and telephone numbers of business subscribers] contained in the directory, they could have extracted all the information that they needed from the list furnished to them by Southern Bell. Instead, Donnelley copied the formatted information .... ." Id at 959.

149. See also cases cited in note 108 .

150. 936 F2d 671 (2d Cir 1991). 
and used by readers to predict the winning numbers for illegal "numbers games." 151 The court described the compilations as follows:

All publishers of the charts at issue use the exact same format: they display the results for periods of thirteen months, showing the months of the year in a row across the top of the chart and the numbers 1 to 31 in a vertical column to indicate the day of the month. Unless a publisher were to make a mistake, the information in the charts does not vary in the slightest as between publishers and is derived from commonly ascertainable external sources. 152

The Second Circuit noted that the Supreme Court in Feist had "relied on the fact that the telephone book's ordering of facts was 'mechanical,' 'typical,' and 'garden-variety' to decide that its selection and arrangement were entirely devoid of creativity, and therefore undeserving of copyright protection." 153 Describing the charts as "purely functional grids that offer no opportunity for variation," 154 the court noted that the plaintiff "exercises neither selectivity in what he reports nor creativity in how he reports it," 155 and thus concluded that the charts lacked originality and were not protected by copyright. ${ }^{156}$

Of the cases following in Feist's wake concerning compilations of data, Project Development Group v. O.H. Materials Corporation 157 may pose the most interesting question. A general contractor, bidding on a project that included the removal of asbestos insulation from a factory being demolished, solicited a bid proposal from a subcontractor for the removal and disposition of the asbestos. The general contractor incorporated some elements of the bid proposal into its own bid for the project, then, after being awarded the project, elected to perform the work itself without using the subcontractor. The subcontractor claimed that it had submitted its bid to the general only on an express understanding that it would be awarded the asbestos removal subcontract if the general received the demolition contract and filed suit.

Among the various counts of the subcontractor's complaint against the general contractor was one for copyright infringement for incorporating elements of the subcontractor's bid into the general contractor's bid. The court phrased the issue and its conclusion in these terms:

By PDG's [the subcontractor] own admission, the actions of OHM [the general contractor] constituting their use of PDG's bid proposal are the use of PDG's: (i) estimates as to scope of work; (ii) contract price; (iii) proposed methodology and process; (iv) quantities; (v) safety procedures; and (vi) technical approach . . . . Estimates of scope of work, price and quantities are all factual. In order for PDG to be entitled to copyright protection in the facts, it must show that there is a modicum of

151. The typical numbers games consists of determining a winning three digit number based on some extraneous event or event that is reported daily in the newspapers. The numbers games discussed in the opinion derived their winning numbers from the total amounts of money bet at various New York area flat tracks each day. Some players of the numbers games believe the winning numbers are not purely random but form a pattern that can be predicted, thus creating a market for the cards which compile this data. Id at 672-73.

152. Id at 672 .

153. Id at 673, quoting Feist, $111 \mathrm{~S} \mathrm{Ct}$ at 1296

154. Id.

155. Id.

156. Id.

157. 766 F Supp 1348 (WD Pa 1991). 
originality in the selection and arrangement of such facts. We find that PDG has not done that. ${ }^{158}$

In reaching its conclusion, the court emphasized that "[t]he bulk of such facts are set forth on forms which were provided by [the factory's owner] to all those wishing to bid on the project." 159

The subcontractor also alleged that its Standard Operating Procedure and its Respirator Program proposals had been copied. These documents compiled industry and governmental standards, together with some additions and editing by the plaintiff. Here the court invoked the merger doctrine, ${ }^{160}$ arguing that because of the limited number of ways this information could be conveyed in the bid format, the copyrightable expression and the uncopyrightable idea were merged, thus placing these materials outside of the scope of copyright protection.

The troublesome aspect of Project Development involves the use of the bid price submitted by the subcontractor. The testimony of the plaintiff's vicepresident, which the court took as credible, was "that it is common in the construction industry to bid the highest price which a contractor believes could win the job. There is no necessary relationship between the estimated cost and the bid price." "161 There was also evidence that the subcontractor had access to prices submitted to the factory owner in an earlier round of bidding. After stating this background, the court simply gave a one sentence conclusion: "The quantities estimated and prices selected, by nature of the estimate and bid process, do not possess the requisite originality under the copyright laws." 162

The problem is that the bidding process seems to invite a good deal of variation from one contractor to another in selecting the precise number that they will put down as their bid. Even if the bidding process is seen as a game based on finding the largest number that will be lower than the next lowest number submitted by another player and yet yield an adequate profit, the differences between bids may be profound. Costs and efficiencies will vary from one subcontractor to another, thus creating different points at which the bid will be profitable. Differences in judgment, errors, optimism and pessimism all have their effect on the determination. Strategies may differ as

158. Id at 1353-54.

159. Id at 1354.

160. Copyright protection does not "extend to any idea, procedure, process, system, method of operation, concept, principle, or discovery, regardless of the form in which it is described, explained, illustrated, or embodied in such work." 17 USC $\$ 102($ b). Normally, protecting the copyrightable expression of an idea or ideas does not create any monopoly in the ideas because of the vast array of alternate means of expressing the same ideas. However, in some cases the ways of expressing an idea are sufficiently limited or even unique that the protection of the expression will necessarily protect the ideas embodied in the work and thus limit the access of the public to those ideas. When the ideas and their expression are inseparable, the expression and idea are said to merge. To preserve the access of the public to the ideas, the merger doctrine will deny copyright protection to expression if it is inseparably merged with the underlying ideas. See generally Abrams, The Law of Copyright at $\$ 3.03$ [B][2] (cited in note 3); see also note 113.

161. Project Development, 766 F Supp at 1354.

162. Id. 
to selecting the price that will be most likely to win the bid. In short, at first blush there seems to be a reasonable range of possible bid prices and use of a fair amount of judgment that is individualistic rather than rote. This would seem to militate for a finding of originality. On the other hand, two other factors militate for a finding of uncopyrightability. One is the merger doctrine, ${ }^{163}$ as the "idea" of a bid at a given price expressed in dollars and cents may be inseparable from its "expression." The other factor is the notion that a single price, however creatively arrived at, is simply de minimis and will not be sufficient to be recognized as a work of authorship. ${ }^{164}$ The difficulty is that the court seemed to rest its denial of copyright protection for price information on the absence of creativity rather than on either of these other two notions. As a fairly reasonable case can be made that the choosing of a bid price by a subcontractor involves the confluence of a number of sophisticated judgments, it may well be that the bid is not only independently originated but also possesses the necessary modicum of creativity to be original, but is appropriately denied copyright protection for other reasons. Thus, the court's determination that copyright does not protect the bid price is probably correct although there may be a legitimate case for it being original.

In Sem-Torq, Inc. v. K Mart Corp. ${ }^{165}$ the Sixth Circuit upheld a trial court finding that a set of signs was not a copyrightable compilation, ${ }^{166}$ quoting several passages from Feist concerning the necessity for some modicum of creativity as a constituent element of originality. The plaintiff conceded there was no such creativity in the individual signs but argued that the signs were grouped together as a compilation. The Sixth Circuit refused to treat the signs as a compilation because they were meant to be sold to consumers individually rather than in sets, and they were so unrelated to each other that

163. See notes 113 and 160 .

164. It is a well-established doctrine that some works are just too basic or fragmentary to be considered original regardless of how independent their creation may be. The Copyright Office Regulations deny copyright registration to "[w]ords and short phrases such as names, titles, and slogans; familiar symbols or designs; mere variations of typographic ornamentation, lettering or coloring; mere listing of ingredients or contents; .. . [b]lank forms, such as time cards, graph paper, account books, diaries, bank checks, scorecards, address books, report forms, order forms and the like," and "[w]orks consisting entirely of information that is common property containing no original authorship, such as, for example: Standard calendars, height and weight charts, tape measures and rulers, schedules of sporting events, and lists of tables taken from public documents or other common sources." 37 CFR $\S 202.1$ (1990). The case law follows the same principle of refusing copyright to minimal elements. For example, in Tompkins Graphics, Inc. v. Zipatone, Inc., 1984 Copyright L Dec (CCH) \ 25,698 at 19,132 (ED Pa 1983), the court denied copyright protection to what it described as "basic geometric shapes."

165. 936 F2d 851 (6th Cir 1991).

166. The signs were double-sided, bearing such phrases as "For Rent/For Sale" (plaintiff's sign) and "For Sale by Owner/House for Sale" (defendants' sign). Id at 852. The Copyright Office had registered the plaintiff's claim to copyright in its signs as a compilation, stating in a letter to plaintiff, "Please note that because of the borderline nature of the authorship forming the basis of the claim, we make the registration with some reservation and under our practice of resolving doubtful claims in favor of registration." Id at $\mathbf{8 5 3}$. When plaintiff attempted to register two later sets of signs, one registration was rejected and the other was apparently registered but then cancelled by the Copyright Office. 
consumers ordinarily would only buy them separately. Thus the set could not be a copyrightable compilation. ${ }^{167}$

2. Works Other Than Compilations. The creativity requirement of Feist has also been discussed in opinions concerning works other than compilations of factual data. In Folio Impressions, Inc. $v$. Byer California, ${ }^{168}$ the Second Circuit was confronted with the issue of whether a repetitive fabric design consisting of original roses placed against an unoriginal background was sufficiently creative and thus original. The artist in question had drawn one rose, duplicated it, and then placed the roses against the background in an asymmetrical pattern. Because the decision of where to place the roses and the orientation of each rose was an artistic decision made by the artist without copying any prior work, the Second Circuit held as clearly erroneous the district court's finding that the pattern of roses, as distinct from their individual design, had not been independently originated. On the issue of the creativity component required by Feist, the court stated that "[a]lthough the arrangement may have required little creative input, it was still [the artist's] original work and, as such, copyrightable."'169

In Runstadler Studios v. MCM Limited Partnership, ${ }^{170}$ the issue of originality was raised with respect to a glass sculpture named "Spiral Motion," that was "composed of 39 clear glass rectangles, overlying each other to form a spiral with approximately 405 degrees of arc."171 The defendants challenged the copyrightability of Spiral Motion, on the grounds of lack of originality. ${ }^{172}$

The court read Feist as holding the issue of originality required two separate inquiries: "independent creation and creativity."173 The issue of independent creativity was resolved on the basis of the evidentiary presumption of validity of the copyright flowing from the registration of the claim of copyright to Spiral Motion within five years of its publication as the defendants had offered no evidence to rebut the presumption. ${ }^{174}$ On the issue of creativity, the defendants argued that Spiral Motion lacked creativity "because the sculpture is simply a combination of uncopyrightable standard shapes." 175 Noting that the level of creativity required by Feist was "extremely low," 176 the court pointed out that "combinations of standard shapes may

167. Id at 855 .

168. 937 F2d 759 (2d Cir 1991).

169. Id at 765, citing Feist, $111 \mathrm{~S}$ Ct at 1287.

170. 768 F Supp 1292 (ND Ill 1991). The court ultimately held the plaintiff's copyright was valid but not infringed by the defendant's sculpture. Id at 1298-99. This discussion of the case is limited to the issue of originality of the plaintiff's sculpture.

171. Id at 1294. "The rectangular glass panes are approximately 24 inches long, $11 / 4$ inches wide, and $3 / 16$-inch thick. The panes are unbeveled and thus have six surfaces." Id.

172. Id.

173. Id at 1295.

174. Id. The Copyright Act provides: "In any judicial proceedings the certificate of a registration made before or within five years after first publication of the work shall constitute prima facie evidence of the validity of the copyright and of the facts stated in the certificate." 17 USC \& 410(c) (1988). See generally Abrams, The Law of Copyright $\$ 10.02[D]$ (cited in note 3).

175. Runstadler Studios, 768 F Supp at 1295.

176. Id, quoting Feist, $111 \mathrm{~S} \mathrm{Ct}$ at 1287. 
possess the requisite creativity necessary for copyright protection,"177 and concluded that " $t]$ he choice of location, orientation and dimensions of the glass panes, and the degree of arc of the spiral, show far more than a trivial amount of intellectual labor and artistic expression on plaintiff's part."178

\section{V}

\section{BEYOND FEIST}

\section{A. Originality, Creativity, Compilations and Databases}

What are the implications of Feist Publications beyond its immediate facts? Feist makes it clear that if the underlying elements of the compilation are facts or are in the public domain, there can be no claim of a copyright violation unless there has been some taking of the compiler's selection, coordination, or arrangement. Second, if the selection, coordination, or arrangement involves such obvious and "practically inevitable" methods or a "timehonored tradition"179 as alphabetical listings, then it will not satisfy the standard of originality. In addition to alphabetical listings, arrangements that are based on numerical order or chronological order where such ordering is obvious and frequently used would seem to lack originality on the same basis as alphabetical telephone book listings.

Where does this leave computerized databases that are compilations of public domain facts? This new and significant industry has looked to copyright for protection from certain types of competition. To return to an example familiar to lawyers, both the WestLaw database of West Publishing company and the Lexis database of Mead Data Central, Inc., provide their subscribers with the full text of current American court decisions. Both acquire the decisions by obtaining copies of the slip sheet opinions and adding the texts to their respective databases. Moreover, both of these services have significantly filled in the earlier decisions that predated the creation of their respective databases.

What if a third competitor entered this market and acquired its database by simply downloading all of the opinions from both Lexis and WestLaw? In response to a charge of copyright infringement, the competitor would respond that all that was taken was the uncopyrighted judicial opinions. ${ }^{180}$ The issue of originality would turn on the question of whether the selection and arrangement of the cases (the data) exhibited originality. Can a selection criteria that uses "all" as its criteria be considered original? As for arrangement, the competitor need not copy that but could originate its own categories for search fields. Moreover, most of the search fields are themselves either facts or otherwise not originated by the databases. The

177. Id, citing cases.

178. Id.

179. Feist, $111 \mathrm{~S} \mathrm{Ct}$ at 1297.

180. This assumes that the competitor would edit out all of the synopses, headnotes, and the like added by West or Mead Data. 
different courts exist as a result of laws and constitutions rather than by any act of authorship. Certainly indexing cases for searches by the court of decision, date of decision, deciding judge, dissenting judges and concurring judges seems to be "practically inevitable." The competitor would clearly be prohibited from copying the programs for storing, indexing, searching and accessing the data used by WestLaw or Lexis, but protecting these programs would not protect the public domain content of the judicial opinions themselves or the facts surrounding the cases such as the deciding judge or date of decision.

But if copyright protection is withdrawn from some databases in the wake of Feist, will that harm or even inhibit the ever important accumulation of databases on which so much of our industry, government, commerce, and other institutions have come to depend? While it is too early to do more than speculate, it really seems doubtful that Feist will have any significant impact. For example, databases that include the New York Times, the Wall Street Journal, and the like are dealing with compilations whose elements are copyrighted in the first place. Consequently, issues of selection, coordination, and arrangement do not have to be reached in an infringement suit.

The impact of Feist on those databases that involve public domain materials such as judicial decisions so far seems to be nil, although it is early yet. Assume for the moment that it would be legal for a competitor to copy the text of all court decisions found in WestLaw and Lexis and incorporate them into a competing database. What is to prevent this from happening, and, if it does happen, what are its likely consequences? Part of the problem that any competitor must face is the need to invest capital to create the competing database and service system even if it does not pay for the data. Are there sufficient savings in downloading cases from Westlaw and Lexis, then editing out the clearly protected parts such as headnotes and synopses, providing the necessary instruction for users, soliciting clients, and the like, to be a financially attractive proposition for the person running the competing database? 181 If not, then the issue of using the facts taken from a database to compete with the database will remain a speculative issue.

Moreover, such services as Lexis and WestLaw are available through private subscription rather than as public utilities. Undoubtedly their contracts forbid their users from copying all of their public domain materials to become competitors. It is only reasonable to expect that such contract

181. This assumes that other costs such as creating the service system, providing instructions to users, soliciting clients, and the like, are equal for both existing firms and potential entrants. If these costs are equal, or sufficiently close to equal that any greater cost to a later entrant does not consume the cost savings on obtaining public domain data from the existing services, then there would be no economic reason why new firms would not take advantage of the cost savings and obtain a "free ride" by downloading their data from the other services. Of course, this is a big, and probably dubious, assumption. The point is that any cost savings in creating a new database cannot be considered in a vacuum apart from the other costs of marketing a viable product.

The author is grateful to the staff editors of Law and Contemporary Problems for bringing this issue to his attention in their letter of February 28, 1992, much of the language of which is borrowed here as clarification. 
restrictions would be enforced, and would include equitable relief that would prohibit the creation or maintenance of a database by copying from WestLaw or Lexis. For this reason, perhaps more than any other, it seems unlikely that there will be a serious market challenge to Westlaw, Lexis, and similar databases of public domain materials.

\section{B. Protection of Compilations Under State Law}

If copyright protection will not protect a database, can the compiler turn to state law and invoke the misappropriation doctrine or other forms of action for unfair competition $\mathbf{1 8 2}$ for protection? The Feist opinion refers to the decision in International News Service $v$. Associated Press, ${ }^{183}$ which suggests that the rather amorphous misappropriation doctrine invoked in Intermational News Service might be available to protect compilations of data. ${ }^{184}$ With the Supreme Court citing International News Service, it is predictable in our litigious society that compilers who have been denied copyright protection will seek alternative legal forms of insulation from competition under the rubric of unfair competition and misappropriation.

1. Preemption of State Law Protection of Compilations. It is submitted that any such state law claims should be preempted under both the preemption scheme embodied in section 301 of the Copyright Act and under the judicial doctrines of constitutional preemption. Section 301 of the Copyright Act provides for a two-pronged inquiry to determine preemption. ${ }^{185}$ Section 301 provides:

[A]II legal or equitable rights that are equivalent to any of the exclusive rights within the general scope of copyright as specified by section 106 in works of authorship that are fixed in a tangible medium of expression and come within the subject matter of copyright as specified by sections 102 and 103, whether created before or after that date and whether published or unpublished, are governed exclusively by this title.

182. The phrase "unfair competition" is one of the most loosely used terms in intellectual property. It is often used as a generic term to describe a variety of torts that share only the causation of some form of economic or competitive injury among businesses. It is also used to describe a number of particular commercial torts, ranging from such classic commercial torts as passing off (one competitor "passes off" its goods or services as those of a competitor), to, at the extreme, an amorphous complaint that boils down to little more than the plaintiff saying that the defendant's competition is resented by the plaintiff, and the court should please stop it because the plaintiff's attorney has just learned a new phrase called "unfair competition." The term "misappropriation" is perhaps equally amorphous. Both "unfair competition" and "misappropriation" allegations have been used to suggest that copying of products, services, business methods, packaging, or other aspects of a commercial endeavor is a per se commercial tort. Trademark cases claim misappropriation of good will; trade secret cases speak of misappropriation of confidential information; and many cases allege misappropriation as a synonym for copying in a commercially competitive context.

183. 248 US 215 (1918), cited in Feist, $111 \mathrm{~S} \mathrm{Ct}$ at 1292.

184. Feist cited International News Service to support its position that copyright did not protect facts even if those facts were embodied in a copyrightable writing of an author. See text accompanying notes 209-212. It also seems that Feist transposed the parties in International News Service. See text accompanying note 212 and its preceding paragraph.

185. See generally Abrams, The Law of Copyright at $\$ 6.03$ (cited in note 3). 
Thereafter, no person is entitled to any such right or equivalent right in any such work under the common law or statutes of any State. ${ }^{186}$

The first question is whether the state law ${ }^{187}$ creates rights which are "legal or equitable rights that are equivalent to any of the exclusive rights within the general scope of copyright as specified by section 106."188 The second question is whether the works protected by such state law rights are "works of authorship that are fixed in a tangible medium of expression and come within the subject matter of copyright as specified by sections 102 and 103, whether created before or after [January 1, 1978] and whether published or unpublished." 189 If both of these questions are answered "yes," then the state law is preempted. It seems entirely clear that any state law that would allow the compiler of a compilation to prevent others from copying the compilation is providing a right that is equivalent to one of the exclusive rights of copyright ${ }^{190}$ in subject matter that is expressly included in the realm of copyright. ${ }^{191}$

Beyond the issue of preemption of state law under the statutory prescription of section 301 , state laws attempting to protect compilations from copying under the rubric of misappropriation or a similar form of unfair competition would still be preempted under the constitutional standards laid down by a series of Supreme Court opinions. ${ }^{192}$

The Court has fluctuated over the years in its approach to the issue of preemption of state law protection of intellectual property. In the companion cases of Sears, Roebuck $\mathcal{F}^{\circ}$ Co. v. Stiffel Co. ${ }^{193}$ and Compco Co. v. Day-Brite Lighting Inc. ${ }^{194}$ the Supreme Court articulated a broad standard of federal preemption in the patent and copyright areas. Justice Black, speaking for the Court,

186. 17 USC \& 301 (a) (1988).

187. For the purpose of preemption, it does not matter whether the state law takes the form of a statute, judicial doctrine, or administrative regulation.

188. 17 USC $\$ 301(a)$. The exclusive rights granted to a copyright owner in section 106 are: "(1) to reproduce the copyrighted work in copies or phonorecords; (2) to prepare derivative works based upon the copyrighted work; (3) to distribute copies or phonorecords of the copyrighted work to the public by sale or other transfer of ownership, or by rental, lease, or lending; (4) in the case of literary, musical, dramatic, and choreographic works, pantomimes, and motion pictures and other audiovisual works, to perform the copyrighted work publicly; and (5) in the case of literary, musical, dramatic, and choreographic works, pantomimes, and pictorial, graphic, or sculptural works, including the individual images of a motion picture or other audiovisual work, to display the copyrighted work publicly." 17 USC $\S 106$ (1988).

189. 17 USC $\$ 301(a)$.

190. Compare 17 USC $\S 106(1)$.

191. Compare 17 USC $\S \S 101,103$ (definition of "compilation").

192. Because of the clear cut preemption under section 301 of the Copyright Act, the coverage of this quite complex issue will be comparatively truncated. For more detailed discussions of this general issue, see Abrams, $1983 \mathrm{~S} \mathrm{Ct} \mathrm{Rev} \mathrm{at} \mathrm{537-66} \mathrm{(cited} \mathrm{in} \mathrm{note} \mathrm{132);} \mathrm{Abrams,} \mathrm{The} \mathrm{Law} \mathrm{of} \mathrm{Copyright}$ at ch 6 (cited in note 3).

193. 376 US 225 (1964).

194. 376 US 234 (1964). These cases alleged infringement of design patents and unfair competition in the copying of a pole lamp (Sears) and a lighting fixture (Compco). Both trial courts invalidated the design patents but granted relief on the grounds of unfair competition. Sears, 376 US at 226; Compco, 376 US at 234-36. The Seventh Circuit affirmed, basing its rulings on the Illinois law of unfair competition. Stiffel Co. v Sears, Roebuck E Co., 313 F2d 115 (7th Cir 1963); Day-Brite Lighting, Inc. $v$ Compco Corp., 311 F2d 26 (7th Cir 1962). The Supreme Court reversed both cases. 
stated that "because of the federal patent laws a state may not, when the article is unpatented and uncopyrighted, prohibit the copying of the article itself or award damages for such copying." 195 He then held:

when an article is unprotected by a patent or a copyright, state law may not forbid others to copy that article. To forbid copying would interfere with the federal policy, found in article I, \& 8, cl 8, of the Constitution and in the implementing federal statutes, of allowing free access to copy whatever the federal patent and copyright laws leave in the public domain. ${ }^{196}$

The scope of constitutional preemption suggested by Sears and Compco was significantly reduced by Goldstein $v$. California, ${ }^{197}$ a case involving a preemption challenge to a California criminal statute198 which prohibited the unauthorized reproduction of sound recordings. ${ }^{199}$ In Goldstein, the Supreme Court took the position for the first time that the copyright-patent clause of the Constitution did not of itself invalidate state intellectual property laws. ${ }^{200}$

Goldstein addressed the question of whether the federal statute required preemption of the state record piracy statute, and adopted the standard of Hines v. Davidowitz: whether the challenged state law "stands as an obstacle to the accomplishment and execution of the full purposes and objectives of Congress."201 The Court reasoned that Congress had left the area of recorded performances "unattended" in the 1909 Copyright Act, ${ }^{202}$ leaving the states free to legislate until such time as Congress might occupy the field. ${ }^{203}$ The issue of a conflict between state law and the federal Copyright Act was avoided by interpreting the federal law so that it did not cover the type of activity the state law sought to regulate. Goldstein thus employed a twotiered inquiry, asking, first, whether the federal statute covered the issue, and, second, whether any failure of coverage by a federal law was the result of a congressional intent to leave the subject area unregulated as part of the overall congressional purpose. Under Goldstein, state laws are not preempted

195. Sears, 376 US at 232-33.

196. Compco, 376 US at 237.

197. 412 US 546 (1973).

198. Cal Penal Code $\S 653 \mathrm{~h}$ (West 1970).

199. Prior to February 15, 1972, the federal Copyright Act did not provide any protection from unauthorized copying to the owner of the rights in the performance embodied in a sound recording, although the owner of the rights in the musical composition that was recorded was protected. This was the result of the compulsory license provisions for the making of sound recordings that were incorporated into the 1909 Copyright Act. See Abrams, The Law of Copyright at $\$ 2.04[\mathrm{C}][3][\mathrm{b}][\mathrm{viii}]$ (cited in note 3). The situation was remedied by the 1971 Sound Recording Amendment, Act of October 15, 1971, Pub L No 92-140, 85 Stat 391 (1971) (effective Feb 15, 1972), codified at 17 USC $\S \S 1(\mathrm{f}, 5(\mathrm{n}), 19,20,26,101(\mathrm{e})(1976)$, repealed 1976; repeal effective Jan 1, 1978, which granted the owners of the rights in the performances the exclusive right to make phonorecords (copies of sound recordings) of these performances. Equivalent provisions were carried over into the current Copyright Act. 17 USC $\S \S 102(a)(7), 106(1), 114$.

The recordings at issue were fixed prior to February 15, 1972, and the validity of state law protection of sound recordings fixed after that date was not at issue in Goldstein. 412 US at $552 \mathrm{n} 7$.

200. 412 US at 552-61. The author was and remains extremely critical of the Supreme Court's reasoning on this issue. See Abrams, $1983 \mathrm{~S} \mathrm{Ct} \mathrm{Rev} \mathrm{at} \mathrm{527-29} \mathrm{(cited} \mathrm{in} \mathrm{note} \mathrm{132).}$

201. Goldstein, 412 US at 561, quoting Hines v Davidowitz, 312 US 52, 67 (1941).

202. See note 199 .

203. 412 US at 569-70. This suggests that every subject-matter issue arising in copyright preemption requires an examination of the relevant congressional history. 
if there is no federal statute on the subject at issue and the lack of such a statute was not part of an overall congressional scheme for regulating the area.

Despite the seeming differences between Goldstein and Sears and Compco, Goldstein explicitly stated that it was reaffirming Sears and Compco.204 This affirmation was accomplished by reading Sears and Compco to hold that where an article is a member of a class of articles (books, machines, data compilations) which are eligible for copyright or patent protection, but the particular article fails to meet the threshold standards for such protection (originality for copyrights; novelty, utility, and nonobviousness for patents ${ }^{205}$ ), then state law may not provide the protection from copying that the federal law denied. If the object cannot obtain federal patent or copyright protection because it is generically ineligible, however, then the states may protect it where the federal laws have left the area "unattended." The issue of eligibility is to be measured by the coverage of the statute rather than the purpose of the constitutional clause, a questionable reading at best. ${ }^{206}$

More recently, the Supreme Court's unanimous opinion in Bonito Boats, Inc. v. Thunder Craft Boats, Inc. ${ }^{207}$ invalidated a Florida statute forbidding copying of original boat hull designs by a technique know as "plug-molding." This manufacturing technique, which can be applied to the duplication of a wide variety of products, uses one boat to create the mold for future boats which would have identical hulls. This technique saves the copier much of the start-up costs that it would otherwise incur to compete with the original boat hull builder. ${ }^{208}$ The argument made for the constitutionality of the statute was that it did not forbid copying, only copying which created an unfair commercial advantage to the copier by allowing it to receive the benefit of originator's expenditures or "reaping where it had not sown."

In its opinion, the Court placed heavy emphasis on both the results and the reasoning in Sears and Compco, indicating that these cases serve as live precedents rather than dormant historical roadmarkers. The state statute was rejected as unconstitutional because it was in conflict with the federal scheme that required novelty and nonobviousness as the prerequisite conditions for legal protection from competition.

204. Id at 571.

205. Graham v John Deere Co., 383 US 1 (1966), and its companion case, United States v Adams, 383 US 39 (1966), are usually considered the classics in this field.

206. This reading of Sears-Compco seeks to explain those decisions on the basis that the design patents on the objects sought to be protected were invalid. Thus the items were members of a class which was generically eligible for design patent protection but failed to meet the standards for a valid patent; whereas, the performances embodied in phonograph records fixed prior to February 15, 1972, were generically ineligible for copyright. Goldstein's rereading of Sears and Compco would render them compatible with Goldstein. However, this effort to resolve the contradictions between the opinions is not convincing. It ignores the thrust of Justice Black's opinions, whose sweeping language suggests the preemption of state intellectual property protection is necessary to give the federal scheme its rational scope. See Howard B. Abrams \& Robert H. Abrams, Goldstein v. California: Sound, Fury E Significance, 1975 S Ct Rev 147, 175-77.

207. 489 US 141 (1989). See Abrams, The Law of Copyright at $\S 6.02[C][5]$ (cited in note 3).

208. Bonito Boats, 489 US at 144. 
Given these precedents, it is difficult to see how any form of state law protection of a compilation can survive a preemption challenge even if it somehow escapes the reach of section 301. Sears and Compco, taken at full tilt, would require no analysis beyond the fact that it provides a form of intellectual property protection to see such a state law as impermissible poaching on a federal preserve. Even after filtering Sears and Compco through Goldstein, the fact remains that those compilations, which are not protected by copyright, are of a genre which is eligible for copyright protection but do not receive it only because they fail to satisfy the threshold requirement of originality and are thus beyond the constitutional reach of state law protection. Goldstein's more generalized tests for statutory preemption section 103's express inclusion of compilations in the subject matter of copyright, and section 101's inclusion of an originality requirement in its definition of "compilation," indicate that Congress did not leave the issue "unattended," thus preempting state law. Finally, the thrust of Bonito Boats is to permit copying of anything which the patent or copyright laws place in the public domain, and is contrary to allowing any state law protection of compilations that fail to gain copyright protection because they lack originality.

2. Feist and International News Service. The consideration of the issue of preemption of state law protection for compilations was in part fueled by Feist's reference to International News Service. ${ }^{209}$ The first point to realize is that Feist only cited International News Service as support for the proposition that facts were not copyrightable, not for the misappropriation doctrine. If anything, Feist's discussion of International News Service and the passages quoted from the International News Service case contradict the actual holding and suggest that there was no restriction on one news service taking facts and reports of facts from another news service:

Decisions of this Court applying the 1909 Act make clear that the statute did not permit the "sweat of the brow" approach. The best example is International News Service $v$. Associated Press .... In that decision, the Court stated unambiguously that the 1909 Act conferred copyright protection only on those elements of a work that were original to the author. Associated Press had conceded taking news reported by International News Service and publishing it in its own newspapers. Recognizing that [section] 5 of the Act specifically mentioned "[p]eriodicals, including newspapers," [section] 5(b), the Court acknowledged that news articles were copyrightable. . . . It flatly rejected, however, the notion that the copyright in an article extended to the factual information it contained: "[T] he news elementthe information respecting current events contained in the literary productionis not the creation of the writer, but is a report of matters that ordinarily are publici juris; it is the history of the day." 210

209. The topic would have been discussed anyway as the author has heard speculation from members of the bar concerning state law as a possible avenue for the protection of databases, but it might not have been discussed in depth and almost certainly would have had a different emphasis had International News Service not been cited by Feist.

210. 111 S Ct at 1292 (citations omitted). 
The footnote that accompanied this quoted paragraph stated: "The Court ultimately rendered judgment for International News Service on noncopyright grounds that are not relevant here."211

A tantalizing error exists in Feist's discussion of the case. The opinion transposes International News Service with Associated Press in this passage and footnote. It was International News Service that was taking AP's news reports and using them as its own, and it was AP that ultimately obtained an injunction against International News Service on noncopyright grounds. It is more likely that compilers will look to state law as an alternative form of intellectual property protection for their compilations if Feist can be read as suggesting this avenue. Given that AP prevailed in the International News Service case on the basis of the misappropriation doctrine, it might be argued that its citation in Feist strengthens the argument for state law protection of compilations.

Perhaps the most interesting line of speculation is whether the error, if known at the time the opinion was written, would have made any difference. The most probable answer is that it would not have made a difference. The transposing of parties in the opinion is consistent and yields a result consistent with the actual opinion. In other words, International News Service is erroneously designated as the originating news service and AP as the copying news service, but International News Service is also erroneously designated as the prevailing party in the litigation.

Although it seems far less likely, there is a possibility that the Feist opinion would not have cited International News Service at all if it was realized that AP rather than International News Service prevailed. If, in fact, the reference to the case had been omitted, this article would be speculating on whether International News Service and the misappropriation doctrine have any continued validity in light of Feist. After all, both cases involve the copying of uncopyrightable facts. ${ }^{212}$ The arguable difference between the two cases, if any, is the currency of AP's facts which lose their status and value as news in a relatively short period of time. If this is indeed a distinction without a difference, then Feist would seem to undercut International News Service rather than support it.

As with many typographic errors, this will presumably be corrected by the time the case is reported in the bound volumes. However, the nature of the correction may itself be the source for further speculation on the preemption issues.

211. Id at $1292 \mathrm{n}^{* *}$ (citations omitted).

212. International News Service's verbatim copying of a significant number of AP's articles probably would have made a finding of copyright infringement attainable in that case. This alone would not have accomplished AP's goals because it would have left International News Service free to continue copying facts from AP's news reports and rewriting them. 


\section{Originality and Derivative Works}

On a broader scale, the Court's remark in Feist Publications that the decision should be regarded "as making clear that copyright rewards originality, not effort," 213 has important implications for cases raising issues of what constitutes originality in other contexts. In an intriguing parallel to the divergent standards of "selection and arrangement" and "sweat of the brow" that polarized the question of the standard of originality in factual compilations, a similar divergence exists in the area of derivative works. ${ }^{214}$ Many derivative works raise the question of whether they are sufficiently different from the original so as to support an independent claim to copyright or whether they so closely resemble the original as to be devoid of any original element.

In the influential case of Alfred Bell $\mathfrak{E}$ Co. $v$. Catalda Fine Arts, Inc., ${ }^{215} \mathrm{Judge}$ Jerome Frank held mezzotint engravings of famous public domain paintings to be copyrightable. Although he acknowledged that the engravers were trying to duplicate the public domain originals as exactly as possible, he noted that the chosen method of engraving made it impossible to produce a photographic replica of the original, and concluded that all the author of the derivative work had to contribute was a "distinguishable variation" on the public domain original. ${ }^{216}$ The "distinguishable variation" standard was invoked by several later cases which sought to protect derivative works that closely resembled the original. The most notorious of these cases was Alva Studios, Inc: $v$. Winninger, ${ }^{217}$ which granted copyright protection to a $3 / 4$ reproduction of the Rodin sculpture "The Hand of God," on the grounds that the difficulty and expense of making the reproduction to scale constituted the requisite originality.

The Second Circuit subsequently reformulated the standard for originality in derivative works in $L$. Batlin $\xi$ Son, Inc. $v$. Snyder, 218 requiring a "substantial as opposed to a trivial variation" 219 to satisfy the requirement of originality. Although it refused copyright protection to a replica of a nineteenth century

213. Feist, $111 \mathrm{~S} \mathrm{Ct}$ at 1297.

214. The Copyright Act defines a derivative work as "a work based upon one or more preexisting works, such as a translation, musical arrangement, dramatization, fictionalization, motion picture version, sound recording, art reproduction, abridgment, condensation, or any other form in which a work may be recast, transformed, or adapted. A work consisting of editorial revisions, annotations, elaborations, or other modifications which, as a whole, represent an original work of authorship, is a 'derivative work.'" 17 USC $\$ 101$ (1988).

215. 191 F2d 99 (2d Cir 195I), aff'g 74 F Supp 973 (SDNY 1947).

216. Id at 102, quoting Gerlach-Barklow Co. v Morris E Bendien, Inc., 23 F2d 159, 161 (2d Cir 1927).

217. 177 F Supp 265 (SDNY 1959).

218. 536 F2d 486 (2d Cir 1976) (en banc), rev'g 187 USPQ 91 (2d Cir 1975). For a sampling of the cases subsequent to Batlin, see, for example, Eden Toys, Inc. $v$ Florelee Undergarment Co., 697 F2d 27 (2d Cir 1982); Original Appalachian Art Works v Toy Loft, Inc., 684 F2d 821, 824-25 (11th Cir 1982); Durham Industries v Tomy Corp., 630 F2d 905 (2d Cir 1980). Perhaps the most extreme case is Gracen v. Bradford Exchange, 698 F2d 300 (7th Cir 1983), but it is difficult to build much analysis on this decision beyond comparing the two pictures reproduced in the reporter, as the opinion confuses the standard for originality with the standard for infringement. See William F. Patry, Latman's The Copyright Law 27 (BNA, 1986).

219. Batlin, 536 F2d at 490 . 
Uncle Sam piggy bank that had greater differences from its public domain original than did the replica Rodin statute in Alva Studios, the Batlin court nonetheless went out of its way to say that Alva Studios was still good law because " $\mathrm{t}] \mathrm{h}$ complexity and exactitude there involved distinguishes that case amply from the one at bar." 220

Feist seems to spell the end of Alva Studios as a viable doctrine. If the Court is to be consistent, then it seems likely that the standard for originality in derivative works would focus on what original contribution of sufficient creativity was made by the preparer of the derivative work. The fact that producing a slavish replica can involve significant cost and effort is no different from the situation where compiling data also involves significant cost and effort. After Feist, originality cannot be found merely in time and expense, nor even in vulnerability to competition. ${ }^{221}$ Feist requires the contribution of some independent and original element to the finished work that makes the work something more than a copy. An exact copy in a different size as a variation on an original work certainly does not seem any more creative than choosing to list names in alphabetical order. Copies that vary in size have become an inescapable, obvious, and indeed a "practically inevitable" cliché. ${ }^{222}$

\section{VI}

\section{Conclusion}

In sum, what are the implications of Feist for future copyright issues? On an immediate doctrinal level, Feist resolved the conflicts of earlier cases and provided a clear answer to the issue of which of the two competing standards should be used. For a compilation of data to qualify for copyright protection, it must exhibit the requisite originality in its selection and arrangement of the data, and that selection and arrangement must display the necessary minimum of creativity. Doctrinally, at least, the "sweat of the brow" test is as dead as the proverbial doornail. 223

More importantly, the originality requirement has been reformulated to explicitly include two distinct elements. To qualify for copyright protection, a work must be the product of both independent origination and a "modicum of creativity." Sheer effort will no longer suffice to establish originality. Equally importantly, Feist firmly and unmistakably reiterates and reinforces the constitutional nature of the originality requirement. Unless and until the Court changes its position, this holding puts any lowering of the originality standard beyond the reach of Congress.

In addition to the arguments in the Feist opinion itself, a major factor favoring the Supreme Court's choice of the "selection and arrangement"

220. Id at 491-92 (emphasis added).

221. See text accompanying note 61 , quoting Feist, $111 \mathrm{~S} \mathrm{Ct}$ at 1289-90.

222. Feist, $111 \mathrm{~S} \mathrm{Ct}$ at 1297 . Also see text accompanying notes 80-88.

223. Feist, $111 \mathrm{~S} \mathrm{Ct}$ at 1291-92. 
standard over the "sweat of the brow" standard is that the Supreme Court's choice is in keeping with the concept of originality in the context of works that are not compilations. In short, it is compatible with both constitutional precedent and common sense notions of originality, while the rejected "sweat of the brow" test is not. The requirement that there be some level of intellectual judgment in the selection, coordination, and arrangement of data that goes beyond steps as obvious as alphabetizing names, is consistent with Bleistein's notion that the originality in a work of authorship reflects the author's personal reaction to the subject. On the other hand, Feist does not require that such a contribution result in a work that is novel, ${ }^{224}$ "innovative," 225 or "surprising"'226 to qualify for copyright protection. Such a reaction may lack sophistication or aesthetic merit, but it is an expression of personality reflecting some form of intellectual and aesthetic judgment. The rejected "sweat of the brow" standard included no such element, only industrious effort, thus making it incompatible with the notions of originality that flow from Bleistein.

The effect of Feist on future production of data compilations seems likely to be minimal. Feist itself expresses the belief that most compilations will be unaffected by the addition of an explicit component of creativity to the requirement of originality. In contemplating the future impact its decision would have on compilations, the Court in Feist stated: "Presumably, the vast majority of compilations will pass this test, but not all will. There remains a narrow category of works in which the creative spark is so utterly lacking or so trivial as to be virtually nonexistent."227 This statement certainly sounds like anything but a wholesale attack on compilations as copyrightable works.

A swallow doth not a summer make, nor two Court opinions a trend. Nonetheless, one significant theme emerges. The two most recent Court cases that have dealt with the scope of intellectual property protection, ${ }^{228}$ Feist and Bonito Boats, Inc. v. Thunder Craft Boats, Inc. ${ }^{229}$ more than any other of the court's copyright opinions over the last decade, adopt a more rigorous approach to intellectual property that is increasingly centered on the copyright-patent Clause of the Constitution. ${ }^{230}$ Feist, in particular, makes a

224. Id at 1294 (“[N]ovelty is not required.”).

225. Id at 1296 .

226. Id.

227. Id at 1294 .

228. Sandwiched in between Feist and Bonito Boats are Community for Creative Nonviolence v. Reid, 490 US 730 (1989), and Stewart v. Abend, $110 \mathrm{~S} \mathrm{Ct} 1750$ (1990). Both of these were concerned with fights between claimants for copyright ownership; neither case raised any issue of the scope of copyright protection with respect to the public.

229. 489 US 141 (1989). See generally Abrams, The Law of Copyright at $\$ 6.02[C][5]$ (cited in note 3).

230. For those who enjoy Court watching, an art form that bears a distinct resemblance to reading tea leaves but nonetheless has its devotees, Feist confirms that Justice O'Connor is currently the Court's designated opinion writer for intellectual property cases. In addition to Feist, her opinions for the Court in the area of intellectual property include Stewart $v$. Abend, $110 \mathrm{~S} \mathrm{Ct} 1750$ (1990), Bonito Boats, Inc. v. Thunder Craft Boats, Inc., 489 US 141 (1989), Harper $E$ Row Publishers, Inc. v. Nation Enterprises, 471 US 539 (1985), and Park 'N Fly, Inc. v. Dollar Park and Fly, Inc., 469 US 189 
distinct effort to ground its reasoning in a consistent set of fundamental constitutional principles. This emphasis on the constitutional framework of copyright as the basis for analysis could be a welcome change from the all too often helter-skelter approach that has characterized other court decisions in the area of copyrights.

Perhaps the greatest importance of Feist rests on a policy perspective. Feist prevents copyright from being used to bar public access to facts and data per se, which copyright was never intended to protect. ${ }^{231}$ Compilations of facts will be subject to at least a minimal test of originality before restrictions on their duplication and dissemination will be recognized. In an increasingly technological society, the "information age," it is reassuring to know that claims to control the reproduction and dissemination of facts per se are not recognized by the Court. The inherent danger of "sweat of the brow" and its progeny has always been its potential for preventing the use and dissemination of facts and data, thus extending copyright beyond the realm of an author's expression. ${ }^{232}$ As the Feist case demonstrates, the costs that monopoly imposes on the public are not limited to merely higher prices, but include the inability of the downstream user to create new works or compilations based on what has gone before. ${ }^{233}$ By insisting that the constitutional requirement of authorship embodied in the standard of originality have some meaningful minimum, the Supreme Court has given the issues in Feist a resolution that is sound both in doctrine and practice, and has done so in an opinion that bodes well for the future.

(1985). Compare Business Guides, Inc. v. Chromatic Communications Enterprises, $111 \mathrm{~S} \mathrm{Ct} 922$ (1991) (Rule 11 sanctions issues arising in the context of a copyright case).

231. The Feist opinion explicitly adopts this consideration as part of its rationale. $111 \mathrm{~S} \mathrm{Cl}$ at $1291-92$.

232. Compare 17 USC $\S 102$ (b) ("In no case does copyright protection for an original work of authorship extend to any idea, procedure, process, system, method of operation, concept, principle, or discovery, regardless of the form in which it is described, explained, illustrated, or embodied in such work."). See also Feist, $111 \mathrm{~S}$ Ct at 1292 (" "[S]weat of the brow' courts . . . handed out proprietary interests in facts and declared that authors are absolutely precluded from saving time and effort by relying upon the facts contained in prior works.").

233. It is worth noting that in Feist, the allegedly infringing directory was not an exact copy of the plaintiff's directory, but combined the information of several of plaintiff's directories into a single, more comprehensive volume, and added street addresses. In the nearly contemporaneous case of Illinois Bell Telephone Co. v. Haines $\mathcal{F}^{3}$ Co., 683 F Supp 1204, the defendant's directories consisted of the same data arranged by telephone number or by street address. The plaintiff's and defendant's directories in Haines were not as directly competitive as those in Feist. 